Supporting Information for

\title{
A Dense-Shell Macromolecular Scaffold for Catalyst- or Substrate-Guided Catalysis in a Cellular Environment
}

Qing Lu ${ }^{\dagger[\mathrm{a}]}$, Silei Bai ${ }^{\dagger[\mathrm{a}]}$, Zhiyong Chen ${ }^{[\mathrm{a}]}$, Nan Zheng ${ }^{[\mathrm{b}]}$, Xinxin Feng ${ }^{[\mathrm{a}]}$ and Yugang Bai ${ }^{[\mathrm{a}] *}$

[a] Institute of Chemical Biology and Nanomedicine, State Key Laboratory of Chem/Biosensing and Chemometrics, Hunan Provincial Key Laboratory of Biomacromolecular Chemical Biology, College of Chemistry and Chemical Engineering, Hunan University, Changsha, Hunan 410082, China

[b] Department of Polymer Science and Engineering, School of Chemical Engineering, Dalian University of Technology, Dalian, Liaoning 116024, China

$\uparrow$ These authors contributed equally.

\section{Table of Contents}

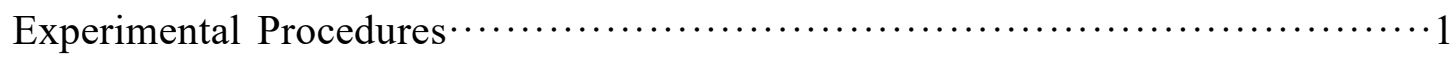

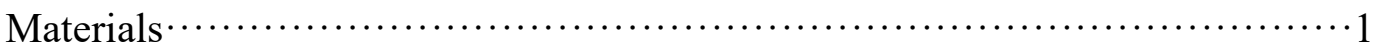

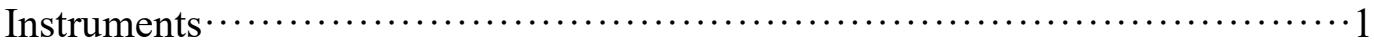

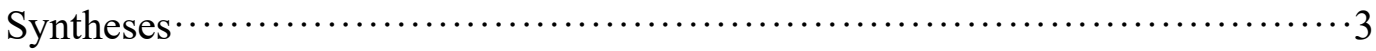

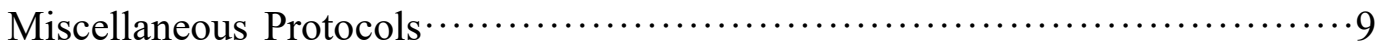

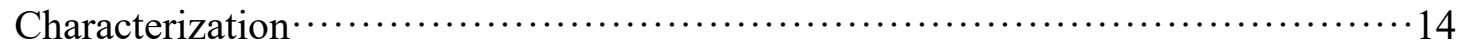

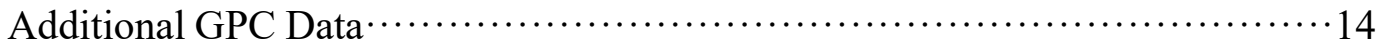

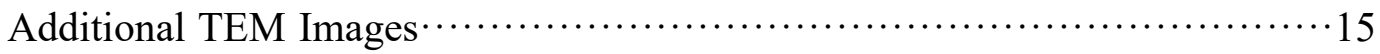

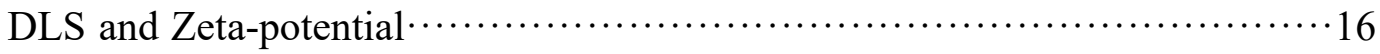

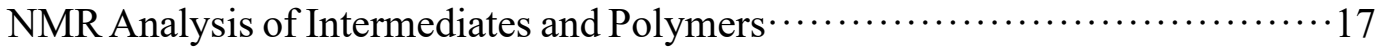

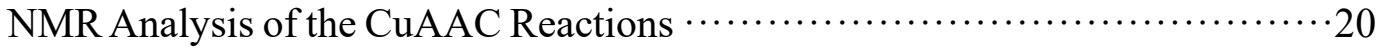

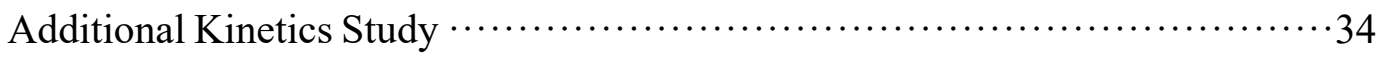

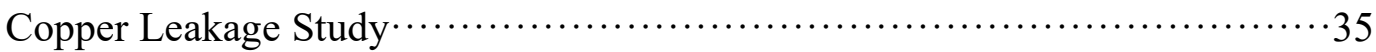

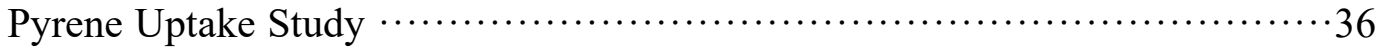

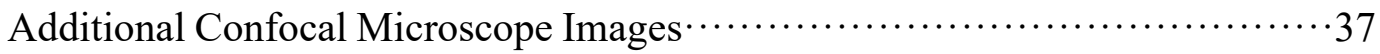

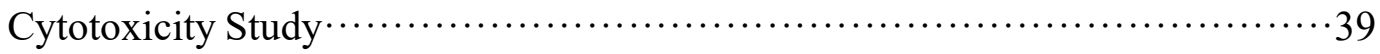

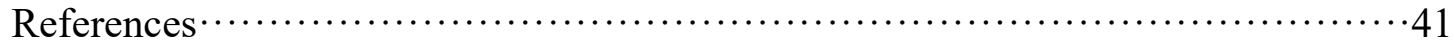




\section{Experimental Procedures}

\section{$\underline{\text { Materials }}$}

All solvents and reagents were purchased from Shanghai Adamas Reagent, Ltd. or Shanghai Macklin Biochemical Co., Ltd. Mito-Tracker Red and polyvinylpyrrolidone mounting medium were purchased from Beyotime Biotechnology (Shanghai). Water was purified by a Milli-Q water purification system. All other solvents were dried and stored over activated $4 \AA$ molecular sieves. Reagents were used without further purification unless otherwise noted. Triethylamine (TEA) and diisopropylethylamine (DIPEA) was dried over $\mathrm{KOH}$ pallets. Pyridine-modified Grubbs $2^{\text {nd }}$ Generation catalyst (also known as Grubbs $3^{\text {rd }}$ Generation catalyst) for ROMP polymerization was synthesized according to a procedure in the literature. ${ }^{[1]}$

\section{Instruments}

Nuclear Magnetic Resonance (NMR). NMR spectra were recorded using a Bruker Avance II $400 \mathrm{MHz}$ spectrometer in the NMR Laboratory, Institute of Chemical Biology and Nanomedicine, Hunan University. The data was processed in MestReNova 6.1 and aligned/annotated in Adobe Illustrator CC or Microsoft Paint of Windows 10.

Mass Spectrometry. High resolution mass spectral analyses were provided by the Mass Spectrometry Laboratory, School of Chemical Engineering, Dalian University of Technology, using an Agilent electron spray ionization (ESI) mass spectrometer instrument.

Analytical Gel Permeation Chromatography (GPC). GPC experiments were performed on a Waters-Wyatt hybrid system equipped with a Waters 515 isocratic pump, a Waters 2414 refractive index detector, and a miniDAWN TREOS II multi-angle laser light scattering detector (MALLS, Wyatt Technology, CA). Separations were performed at $50{ }^{\circ} \mathrm{C}$ using PLgel PL1110-6530/6540/6550 columns (Agilent) and DMF containing $0.1 \mathrm{M} \mathrm{LiBr}$ as the mobile phase. The detection wavelength of TREOS was set at 658 
nm. The MALLS detector was calibrated using pure toluene and used for the determination of absolute molecular weights. The molecular weight of all linear polymers was determined based on the $d \mathrm{n} / d \mathrm{c}$ value of each sample calculated offline by using the internal calibration system processed by the ASTRA software. The obtained data points were imported into OriginPro (version 8.1), plotted, and saved as vector image files (*.ai) for coloring and annotation in Adobe Illustrator CC.

Transmission Electron Microscopy (TEM). TEM experiments were conducted on a JEM-2100 Plus transmission electron microscope. For sample preparation, $20 \mu \mathrm{L}$ of DSNP 5 was added on the copper grid, dried at room temperature overnight, and used directly for imaging.

DLS and Zeta-Potential Measurement. Dynamic light scattering and zeta-potential experiments were performed using a Malvern Zetasizer Nano ZSP (Malvern Instruments, UK). Each experiment was independently conducted at least 3 times to confirm the reproducibility. Representative figure and digital result were directly taken from the instrument software's report.

UV-vis Spectroscopy. UV-vis measurements were carried out on a Cary 60 UV-vis spectrometer (Agilent Technologies). The obtained data points were imported into OriginPro (version 8.1), plotted and smoothed, and saved as vector image files (*.ai) for coloring and annotation in Adobe Illustrator CC.

Fluorescence Spectroscopy. Fluorescence intensities were measured by a HITACHI F-7000 fluorescence spectrophotometer. The obtained data points were imported into GraphPad Prism 6, plotted, and saved as vector image files (*.eps) for coloring and annotation in Adobe Illustrator CC.

Inductively Coupled Plasma Mass Spectrometry (ICP-MS). ICP-MS analysis of copper content in the solution was performed on an Agilent 7900 ICP-MS spectrometer equipped with a SPS 4 autosampler. A calibration curve (0 to $500 \mathrm{ppb} \mathrm{Cu})$ was generated before the sample was analyzed, and the concentration of $\mathrm{Cu}$ in the solution was obtained according to the calibration curve. 
Confocal Microscopy. Fluorescence microscope images were acquired using a Nikon Eclipse Ti2-E Laser Confocal Microscope. For coumarin derivatives, wavelengths were set at $405 \mathrm{~nm}$ for excitation, $482 \mathrm{~nm}$ for emission. For imaging of MitoTracker Red CMXRos, wavelengths were set at $561 \mathrm{~nm}$ for excitation, and $595 \mathrm{~nm}$ for emission.

\section{Syntheses}

\section{Synthesis of the Dibromide Monomer}

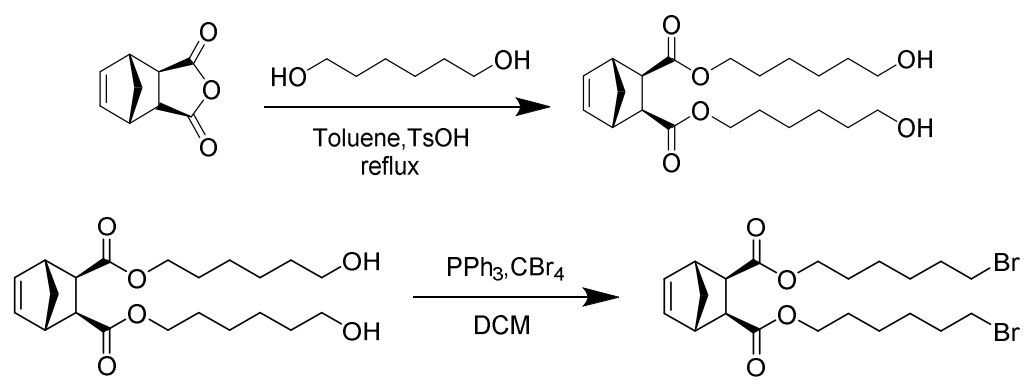

This monomer was synthesized following a reported procedure. ${ }^{[2]}$ All characterization results of the product were consistent with the previously reported data.

\section{Synthesis of the Crosslinker, 1}

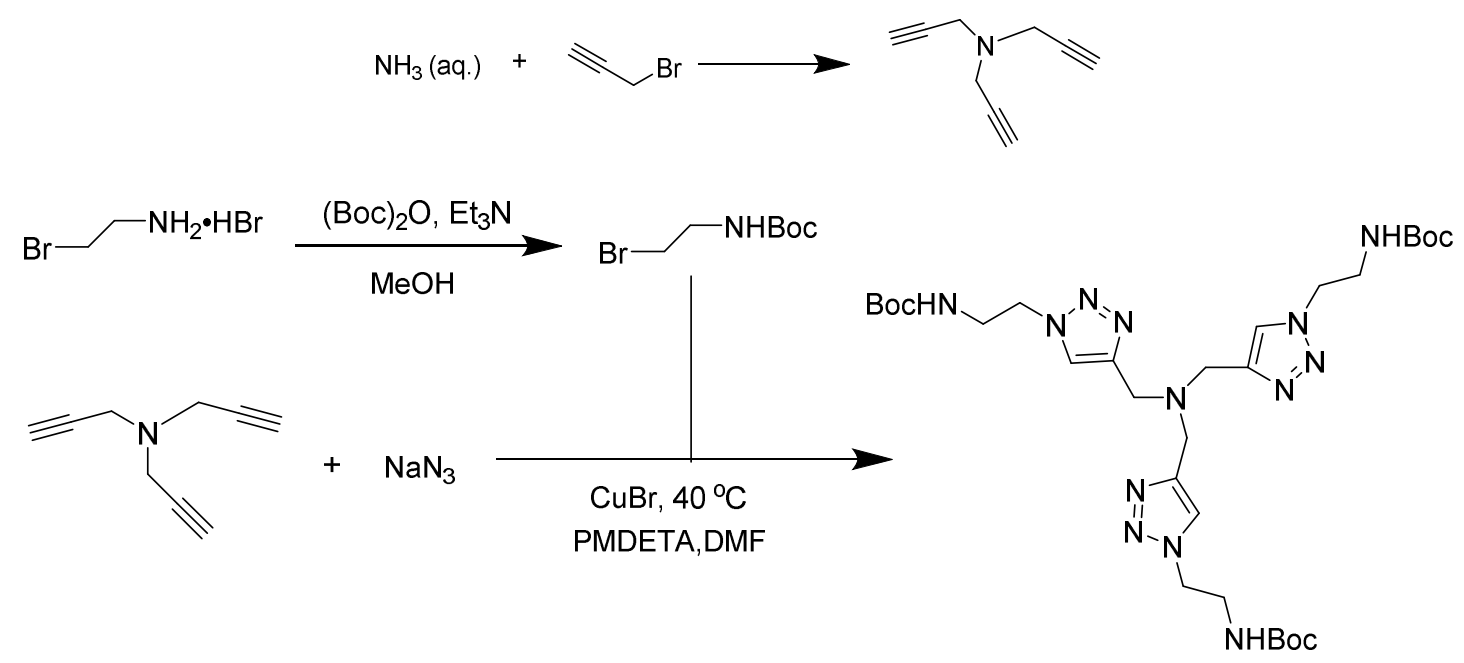

Synthesis of tripropargylamine

This monomer was synthesized following a reported procedure. ${ }^{[3]}$ All characterization results of the product were consistent with the previously reported data. 


\section{Synthesis of N-Boc-2-bromoethylamine}

A solution of (Boc) $)_{2} \mathrm{O}(21.30 \mathrm{~g}, 97.6 \mathrm{mmol}, 2$ eq. $)$ in $\mathrm{MeOH}(80 \mathrm{~mL})$ was added over a period of $0.5 \mathrm{~h}$ to a solution of 2-bromoethylamine hydrobromide (10 g, $48.8 \mathrm{mmol}, 1$ eq.) and $\mathrm{Et}_{3} \mathrm{~N}$ (10.87 g, $107.4 \mathrm{mmol}, 2$ eq.) in $\mathrm{MeOH}(60 \mathrm{~mL})$. The mixture was stirred for $18 \mathrm{~h}$ at room temperature. The reaction mixture was concentrated to dryness in vacuo to give a residue, which was added water $(100 \mathrm{~mL})$ and extracted with $\mathrm{CH}_{2} \mathrm{Cl}_{2}$ $(3 \times 50 \mathrm{~mL})$. The combined extracts were dried $\left(\mathrm{MgSO}_{4}\right)$ and concentrated to dryness to afford the product as a colorless oil $(9.0 \mathrm{~g}, 82.6 \%)$. This product was pure enough to be directly used in the next step. Characterization results of the product matched previous literature reported data. ${ }^{[4]}$

\section{Synthesis of the Boc-protected tris-triazole-amine}

$N$-Boc-2-bromoethylamine (1.30 g, $5.81 \mathrm{mmol}, 3.5$ eq.), sodium azide (1.51 g, 23.2 mmol, 14 eq.) and tripropargylamine $(218 \mathrm{mg}, 1.66 \mathrm{mmol}, 1$ eq. $)$ were added into a two-neck round bottom flask containing DMF $(10 \mathrm{~mL})$. The mixture was added $\mathrm{CuBr}$ (36 mg, $0.25 \mathrm{mmol}, 0.150$ eq.), PMDETA (47 mg, $0.27 \mathrm{mmol}, 0.165$ eq.), and the mixture was stirred overnight at $40^{\circ} \mathrm{C}$. Water $(100 \mathrm{~mL})$ was added to the reaction mixture, and the resulting mixture was extracted with EtOAc $(3 \times 60 \mathrm{~mL})$. The combined organic extracts were washed with brine three times, dried with anhydrous $\mathrm{MgSO}_{4}$ and concentrated to dryness in vacuo to give a crude product as a yellow oil, which was further purified by column chromatography $\left(\mathrm{CH}_{2} \mathrm{Cl}_{2} / \mathrm{MeOH}, 30: 1\right.$ to $\left.20: 1\right)$ to afford the pure product as a light yellow solid (565 mg, 49\%). ${ }^{1} \mathrm{H}$ NMR (400 MHz, $\left.\mathrm{CDCl}_{3}\right): \delta 7.74(s, 3 \mathrm{H}), 5.22(s, 3 \mathrm{H}), 4.48(t, J=5.2 \mathrm{~Hz}, 6 \mathrm{H}), 3.84(s, 6 \mathrm{H}), 3.65$ (broad, $6 \mathrm{H}), 1.45(s, 27 \mathrm{H}) .{ }^{13} \mathrm{C} \mathrm{NMR}\left(100 \mathrm{MHz}, \mathrm{CDCl}_{3}\right): \delta 155.9,144.4,124.3,79.9,50.1$, 48.0, 40.6, 28.4. High-resolution ESI-MS: calculated for $\mathrm{C}_{30} \mathrm{H}_{51} \mathrm{~N}_{13} \mathrm{O}_{6}{ }^{+}\left(\mathrm{M}^{+}\right): 689.4085$, found $728.3723\left([\mathrm{M}+\mathrm{K}]^{+}\right)$. 


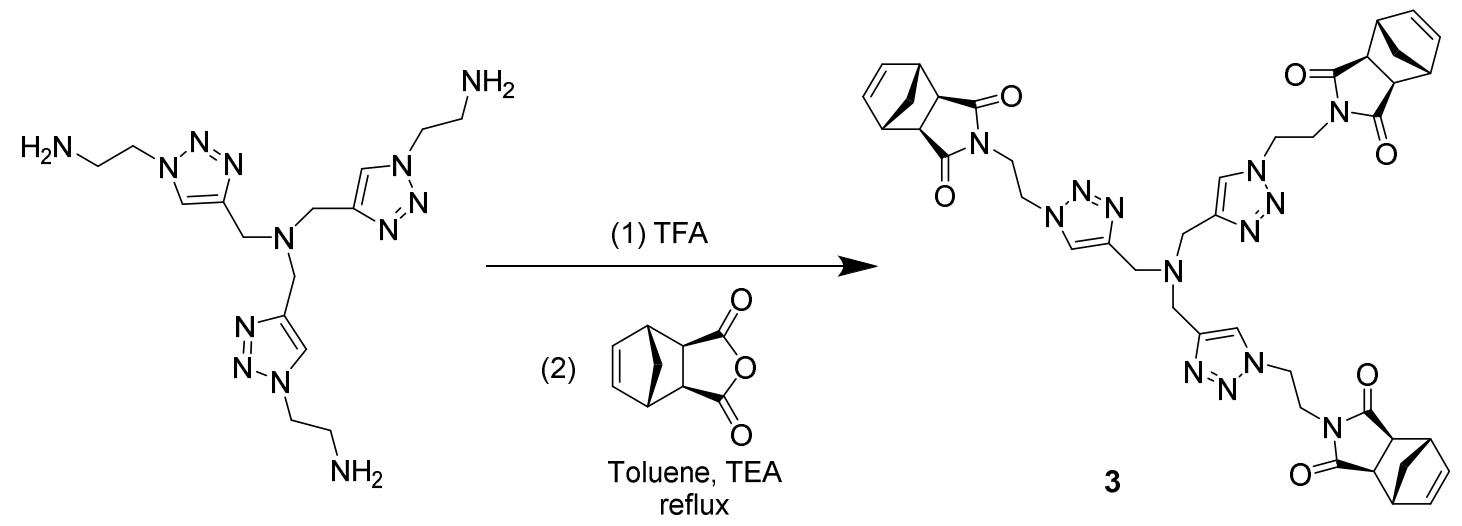

Synthesis of crosslinker 3

The Boc-protected tris-triazole-amine can be removed with 50\% trifluoroacetic acid in DCM for 4 hours, then the reaction mixture was concentrated to dryness in vacuo to give a residue, giving the pure triamine as a trifluoroacetate salt. The product was directly used in the next step without purification. A round-bottom flask was charged with deprotected tris-triazole-amine (500 mg, $0.59 \mathrm{mmol}, 1$ eq.), cis-5-norbornene-exo2,3-dicarboxylic anhydride (695 mg, $4.24 \mathrm{mmol}, 7.2$ eq.), triethylamine (518 mg, 5.12 mmol, 8.7 eq.) and toluene $(15 \mathrm{~mL})$. The reaction mixture was heated to reflux for $8 \mathrm{~h}$ before it was concentrated under reduced pressure to yield a yellow solid. The residue was re-dissolved in $\mathrm{CH}_{2} \mathrm{Cl}_{2}(80 \mathrm{~mL})$ and washed first with $1 \mathrm{~N}$ sodium hydroxide solution containing ethanolamine, then with brine for three times. The organic layer was dried over $\mathrm{MgSO}_{4}$ and concentrated under vacuum to yield crude 3 as a light yellow solid, which was purified by column chromatography $\left(\mathrm{CH}_{2} \mathrm{Cl}_{2} / \mathrm{CH}_{3} \mathrm{OH}, 25: 1\right)$ to give the pure product as a white solid (450 mg, 92\%). ${ }^{1} \mathrm{H}$ NMR (400 MHz, $\left.\mathrm{CDCl}_{3}\right): \delta 7.83$ $(s, 3 \mathrm{H}), 6.25(s, 6 \mathrm{H}), 4.60(t, J=5.6 \mathrm{~Hz}, 6 \mathrm{H}), 3.96(t, J=5.6 \mathrm{~Hz}, 6 \mathrm{H}), 3.72(s, 6 \mathrm{H}), 3.20$ $(s, 6 \mathrm{H}), 2.67(s, 6 \mathrm{H}), 1.49(d, J=9.9 \mathrm{~Hz}, 3 \mathrm{H}), 1.23(d, J=9.9 \mathrm{~Hz}, 3 \mathrm{H}) .{ }^{13} \mathrm{C}$ NMR $(100$ $\left.\mathrm{MHz}, \mathrm{CDCl}_{3}\right): \delta 177.44,144.79,137.80,124.01,47.89,47.26,47.02,45.12,42.91$, 38.44. High resolution ESI-MS $(m / z)$ : Calculated for $\mathrm{C}_{42} \mathrm{H}_{46} \mathrm{~N}_{13} \mathrm{O}_{6}{ }^{+}\left([\mathrm{M}+\mathrm{H}]^{+}\right)$: 828.3689; found 828.3691 .

\section{Synthesis of the DSNP Scaffold, 4}

The dibromide monomer $(40.0 \mathrm{mg}, 78.7 \mu \mathrm{mol}, 50$ eq.) was added to a 20 -mL glass vial, 
and $\mathrm{CH}_{2} \mathrm{Cl}_{2}(4 \mathrm{~mL})$ was added to dissolve the solid. Grubbs $3^{\text {rd }}$ generation catalyst 2 (63.0 $\mu \mathrm{L}, 25 \mathrm{mM}$ in chloroform, 1 eq.) was quickly added to the solution with fast stirring. The reaction was allowed for $15 \mathrm{~min}$. A meta-stable solution of $\mathrm{HPF}_{6}$ salt of cross-linker 3 was freshly prepared by mixing 3 (13.3 $\mathrm{mg}, 15.7 \mu \mathrm{mol}$ in $1 \mathrm{~mL}$ of DCM, 10 eq.) with $\mathrm{HPF}_{6}(11.6 \mu \mathrm{L}, 60 \%$ in water $)$ and $t$-butanol $(150 \mu \mathrm{L})$ in a $2-\mathrm{mL}$ vial. Once mixed, the mixture was immediately transferred to the polymerization vial, and DCM $(1 \mathrm{~mL})$ was used to rinse the $2-\mathrm{mL}$ vial before it was added into the reaction vial. The stirring was continued for $4 \mathrm{~h}$. Ethyl vinyl ether (200 $\mu \mathrm{L}$, excess) was added to quench the polymerization. DCM and excess ethyl vinyl ether were removed in vacuo. The residue was purified by repeated ether precipitation and centrifugation to obtain DSNP 4 as an off-white solid (41 mg, $77 \%$ ). Measured dn/dc for the polymer: 0.077 .

Note: the star polymer synthesis has inevitable randomness. Molecular weight obtained from repeated experiment can vary $( \pm 15 \%)$ to some extent and polydispersity ranges from 1.09 to 1.25 .

${ }^{1} \mathrm{H}$ NMR of the polymer (Figure S5, $400 \mathrm{MHz}, \mathrm{CDCl}_{3}$ ): $\delta$ 5.1-5.6 (multiple broad, alkenyl $\mathrm{H}$ on backbone), 4.0 (broad, $-\mathrm{COOCH}_{2}-$ ), 3.4 (broad, $-\mathrm{CH}_{2} \mathrm{Br}$ ), 2.8-3.5 (multiple broad, polynorbornene backbone), 1.1-2.1 (multiple broad, $-\mathrm{CH}_{2} \mathrm{CH}_{2} \mathrm{CH}_{2} \mathrm{CH}_{2} \mathrm{CH}_{2} \mathrm{Br}$, and the bridge $\mathrm{CH}_{2}$ on polynorbornene backbone). For more discussions, see the notes below Figure S5.

\section{Synthesis of the Water-soluble DSNP Scaffold, 5}

The polymer was quaternized with $N$-butylimidazole to give a positive charged DSNP, 5. To a vial containing the Br-functionalized DSNP 4 (40 mg) was added DMF (500 $\mu \mathrm{L})$, acetonitrile $(500 \mu \mathrm{L})$ and $N$-butylimidazole $(160 \mu \mathrm{L}$, excess). The reaction vial was capped, sealed by parafilm, and heated to $50{ }^{\circ} \mathrm{C}$ for $24 \mathrm{~h}$. Solvents were removed under reduced pressure. The residue was dissolved in ethanol $(0.5 \mathrm{~mL})$ and the solution was added into diethyl ether $(13 \mathrm{~mL})$ in a centrifuge tube. The resulting heterogeneous mixture was sonicated. The precipitates were isolated by centrifugation and the 
supernatant was discarded. This process was repeated twice, and the solid was collected and dried. Ultra-pure water was added to dissolve the precipitates, and $\mathrm{NaOH}(20$ $\mathrm{mg} / \mathrm{mL}, 80 \mu \mathrm{L}$, excess) was added to the solution before was dialyzed against water for for 1 day. The purified solution of 5 (containing $35 \mathrm{mg}$ product) was directly used for following studies. Note: the concentration of 5 was measured by taking a small amount of solution, lyophilizing, and weighing the resulting solid, because 4 does not redissolve in water very well after lyophilization.

${ }^{1} \mathrm{H}$ NMR of the polymer (Figure $\mathrm{S} 6,400 \mathrm{MHz}, \mathrm{D}_{2} \mathrm{O}$ ): $\delta 7.5$ (broad, protons on $\mathrm{C} 4$ and C5 of imidazolium ring), 5.1-5.5 (very broad, alkenyl H on backbone), 4.1 (broad, methylene groups next to imidazolium), 3.9 (broad, $\mathrm{COOCH}_{2}-$ ), 2.6-3.5 (multiple, very broad, polynorbornene backbone), 0.8-2.1 (multiple broad, alkyl chains and the bridge $\mathrm{CH}_{2}$ on polynorbornene backbone). For more discussions, see the notes below Figure S6.

Synthesis of Azidocoumarin Substrate 8. This compound was synthesized following a previously reported procedure. ${ }^{[5]}$ Characterization results matched literature reported data.

Synthesis of Substrate 10. This compound was synthesized following a previously reported procedure. ${ }^{[6]}$ Characterization results matched literature reported data.

Synthesis of Substrate 11. This compound was synthesized following a previously reported procedure ${ }^{[7]}$ Characterization results matched literature reported data.

\section{Synthesis of the Fluorescein-Labeled DSNP Scaffold}

Synthesis of 5(6)-carboxyfluorescein monomer 

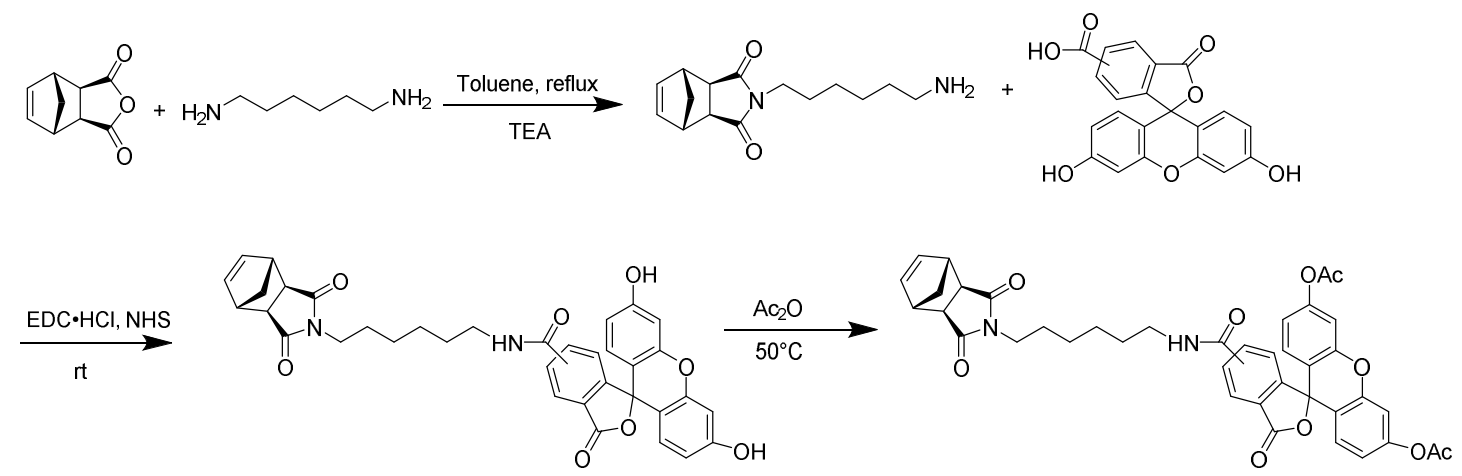

This monomer was synthesized following a literature procedure but using cis-5norbornene-exo-2,3-dicarboxylic anhydride as the starting material instead of the endoanhydride. ${ }^{[8]}{ }^{1} \mathrm{H}$ NMR (400 MHz, DMSO): $\delta 8.81(t, J=5.5 \mathrm{~Hz}, 0.6 \mathrm{H}), 8.65(t, J=5.5$ $\mathrm{Hz}, 0.4 \mathrm{H}), 8.52(s, 0.6 \mathrm{H}), 8.29(d d, J=8.1,1.4 \mathrm{~Hz}, 0.6 \mathrm{H}), 8.21(d d, J=8.1,1.2 \mathrm{~Hz}$, $0.4 \mathrm{H}), 8.15(d, J=8.1 \mathrm{~Hz}, 0.4 \mathrm{H}), 7.80(s, 0.4 \mathrm{H}), 7.53(d, J=8.1 \mathrm{~Hz}, 0.6 \mathrm{H}), 7.30-7.33$ $(m, 2 \mathrm{H}), 6.92-6.99(m, 4 \mathrm{H}), 6.30(m, 2 \mathrm{H}), 3.27-3.38$ ( $m$, overlapping with solvent peak), $3.29(d, J=7.0 \mathrm{~Hz}, 4 \mathrm{H}), 3.17(d d, J=13.0,6.7 \mathrm{~Hz}, 0.4 \mathrm{H}), 3.09(m, 1 \mathrm{H}), 2.68(m, 1 \mathrm{H})$, $2.30(s, 6 \mathrm{H}), 1.15-1.59(\mathrm{~m}, 8 \mathrm{H}) \cdot{ }^{13} \mathrm{C} \mathrm{NMR}$ was not attempted because the product is a mixture of isomers. High-resolution ESI-MS: calculated for $\mathrm{C}_{40} \mathrm{H}_{37} \mathrm{~N}_{2} \mathrm{O}_{10}{ }^{+}\left([\mathrm{M}+\mathrm{H}]^{+}\right)$: 705.2673, found $705.2675\left([\mathrm{M}+\mathrm{H}]^{+}\right)$.

\section{Synthesis of the fluorescein-labeled scaffold}

The synthesis of the fluorescein-labeled DSNP scaffold was analogous to the above mentioned procedure for DSNP. The only difference in the procedure was the addition of 5(6)-carboxyfluorescein monomer in the polymerization stage. Specifically, in the very beginning of the synthesis, the dibromide monomer $(40.0 \mathrm{mg}, 78.7 \mu \mathrm{mol}, 50 \mathrm{eq}$. and 5(6)-carboxyfluorescein monomer (1.1 mg, $1.6 \mu \mathrm{mol}, 1$ eq.) was added to a $20-\mathrm{mL}$ glass vial, and $\mathrm{CH}_{2} \mathrm{Cl}_{2}(4 \mathrm{~mL})$ was added to dissolve the mixture. Grubbs $3^{\text {rd }}$ generation catalyst 2 (63.0 $\mu \mathrm{L}, 25 \mathrm{mM}$ in chloroform, 1 eq.) was quickly added to the solution with fast stirring. All the following procedures were the same. 


\section{Miscellaneous Protocols}

CuAAC Coupling Using Various Substrates. To validate the generality of Cu-DSNP catalysis, the cycloaddition reactions of multiple substrate pairs were investigated. A representative protocol for the study is described as follows:

A solution of $\mathrm{Cu}^{\mathrm{II}}-\mathrm{DSNP} 6$ was freshly prepared by mixing $\mathrm{CuSO}_{4}(10 \mu \mathrm{L}, 500 \mu \mathrm{M}$ in water, $5 \mathrm{nmol})$ and DSNP $5(40 \mu \mathrm{L}, 1.1 \mu \mathrm{M}$ in water, containing $15 \mathrm{nmol}$ of tris-triazole moiety) in water $(0.43 \mathrm{~mL})$ in a $2-\mathrm{mL}$ vial with a magnetic stirrer. The solution of 6 was used "as is" without any further purification or work-up, thus the Cu content in DSNP would match exactly the amount of $\mathrm{CuSO}_{4}$ added. Phenylacetylene $(0.12 \mathrm{mmol})$ and benzyl azide $(0.10 \mathrm{mmol})$ were added to the bottom of the vial. Sodium $L$-ascorbate (2

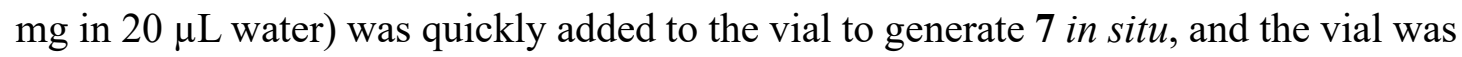
capped, sealed with parafilm, heated to $50{ }^{\circ} \mathrm{C}$ with stirring for $24 \mathrm{~h}$. The reaction mixture was cooled to room temperature, extracted by $\mathrm{CDCl}_{3}$ for three times, and the combined extracts were characterized by ${ }^{1} \mathrm{H}$ NMR. The yield of the reaction was calculated by comparing the integration of the peak corresponding to the methylene in benzyl azide and the product, respectively.

Note: since the DSNP is highly soluble in water, it could hardly be extracted into organic layer and was thus removed. Trace amount of DSNP, if any (emulsification caused contamination) could be efficiently removed by silica gel column chromatography due to its high polarity from positive charges.

Preliminary Study on the Recyclability of DSNP. Following the previous step, after the product were extracted out, additional substrates and sodium ascorbate could be added into the aqueous phase to trigger another batch of synthesis. The yield was lower on this scale $(\sim 70-75 \%)$, presumably because of the remaining ascorbate and misc contents from oxidation and decomposition of ascorbate.

For larger scale synthesis, the DSNP can be fully recycled by dialyzing the aqueous phase containing DSNP against water. We consider large scale click outside the scope 
of this communication and did not study this further.

Kinetics Study. To test DSNP 7's activity at low substrate and catalyst concentrations, azidocoumarin 8, a well-known fluorogenic coumarin derivatives that "light up" upon alkyne-azide cycloaddition, was used as a substrate. $8(5 \mu \mathrm{L}, 0.96 \mathrm{mM}$ in DMSO $)$ and an alkyne $(5 \mu \mathrm{L}, 1.92 \mathrm{mM}$ in DMSO) were added into a solution of 6 in PBS (225 $\mu \mathrm{L}$, formed by mixing 5 and $\mathrm{CuSO}_{4}$ in PBS, tris-triazole: $\mathrm{Cu}=3: 1$ ) in a mini $\mathrm{UV}$ cuvette. The starting concentrations of $\mathbf{8}$ and the selected alkyne were 20 and $40 \mu \mathrm{M}$, respectively. Sodium ascorbate $(5 \mu \mathrm{L}, 200 \mathrm{mM}$ in water) was added into the cuvette. The cuvette was quickly capped, thoroughly mixed on a vortex mixer, and placed in a fluorometer for measurement (excitation $=410 \mathrm{~nm}$, emission $=481 \mathrm{~nm}$ ). The fluorescence intensity of the solution was measured every $2 \mathrm{~min}$, and the intensities were recorded and plotted against time.

Pyrene Uptake Study. To have a more quantitative characterization of Cu-DSNP's ability to bind hydrophobic substrates, the uptake of pyrene as a hydrophobic guest by 6 was quantified by UV-vis. Pyrene in a vial was added the solution of $6(1.7 \mu \mathrm{M})$ or PBS, thoroughly mixed, and filtered. The solution was transferred into a UV cuvette, and its absorbance was measured by a UV-vis spectrometer.

Cell Culture. The HEK293T and NIH/3T3 cell lines were cultured in DMEM medium (Gibco, catalog number C11995500BT) supplemented with 10\% FBS (EVERY GREEN, catalog number $13011-8611$ ) at $37{ }^{\circ} \mathrm{C}$ in a humidified $5 \% \mathrm{CO}_{2}$-containing balanced-air incubator. The cells were seeded into 96-well plates (BIOFIL, catalog number TCP-011-096) at $1 \times 104$ cells per well and incubated for $12 \mathrm{~h}$ at $37{ }^{\circ} \mathrm{C}$ in $5 \%$ $\mathrm{CO}_{2}$ to ensure full confluency.

Representative Protocol for CuAAC Click Experiment. 300,000 NIH/3T3 cells 
were seeded into a well of a glass bottom cell culture dish. For each well, the final volume was $1.5 \mathrm{~mL}$. Cells were incubated 18 to $24 \mathrm{~h}$ to be attached to the plate. The cell medium was removed, and the cells were washed 4 times with PBS (1 mL). After washing, $1.5 \mathrm{~mL}$ of PBS with or without $\mathrm{Cu}^{\mathrm{II}}$-DSNP 6 (concentration in PBS was 125 $\mathrm{nM}$, containing $15 \mu \mathrm{M} \mathrm{Cu}$ ) was added. The cells were incubated for $0.5 \mathrm{~h}$ at $37^{\circ} \mathrm{C}$ in an incubator with a $5 \% \mathrm{CO}_{2}$ atmosphere. PBS (with or without 6) was removed and cells were washed again with PBS (1 mL) for 4-5 times. The two substrates were added in the new PBS incubation solution $(1.5 \mathrm{~mL})$ at a final concentration of $150 \mu \mathrm{M}$, together with $2 \mathrm{mM}$ sodium $L$-ascorbate. The cells were incubated in the incubation solution for 1.5 to $2 \mathrm{~h}$ at $37{ }^{\circ} \mathrm{C}$ in an incubator with $5 \% \mathrm{CO}_{2}$ atmosphere. For mitochondrial staining by MitoTracker Red CMXRos (diluted to $200 \mathrm{nM}$ in PBS), cells were fully immersed in $1 \mathrm{~mL}$ of staining solution and incubated at $37^{\circ} \mathrm{C}$ in an incubator with a $5 \% \mathrm{CO}_{2}$ atmosphere for 15 minutes. Staining solution was removed from cells, and $4 \%$ paraformaldehyde fixing solution $(1 \mathrm{~mL})$ was added and cells were incubated for $15 \mathrm{~min}$ at 20 to $25^{\circ} \mathrm{C}$ to be fixed, before they were washed 3 times with $1 \mathrm{~mL}$ of PBS for 2-5 min. Polyvinylpyrrolidone mounting medium $(50 \mu \mathrm{L})$ was added and cells were taken to a confocal microscope for imaging.

Note: incubation time and concentration of the DSNP and substrates were tunable. For membrane staining, DSNP was incubated for $0.5 \mathrm{~h}$ with a concentration of $125 \mathrm{nM}$ in PBS (containing $15 \mu \mathrm{MCu}$ ), and the substrates/NaAsc were incubated for $45 \mathrm{~min}$ with a concentration of 150/2000 $\mu$ M in PBS. For more intracellular products, DSNP was incubated for $0.5 \mathrm{~h}$ with a concentration of $125 \mathrm{nM}$ in PBS (containing $15 \mu \mathrm{MCu}$ ), and the substrates/NaAsc were incubated for 1.5-2 $h$ with a concentration of 150/2000 $\mu \mathrm{M}$ in $P B S$.

\section{Representative Protocol for Palladium Deprotection Experiment. 300,000} $\mathrm{NIH} / 3 \mathrm{~T} 3$ cells were seeded into a well of a glass bottom cell culture dish. For each well, the final volume was $1.5 \mathrm{~mL}$. Cells were incubated 18 to $24 \mathrm{~h}$ to be attached to the plate. 
The cell medium was removed, and the cells were washed 4 times with PBS (1 mL). After washing, $1.5 \mathrm{~mL}$ of PBS with or without Pd ${ }^{\mathrm{II}}$-DSNP 12 (concentration in PBS was $228 \mathrm{nM}$, containing $40 \mu \mathrm{M} \mathrm{Pd}$ ) was added. The cells were incubated for $0.5 \mathrm{~h}$ at $37{ }^{\circ} \mathrm{C}$ in an incubator with a $5 \% \mathrm{CO}_{2}$ atmosphere. PBS (with or without 12) was removed and cells were washed again with PBS $(1 \mathrm{~mL})$ for $4-5$ times. The substrate was added in the new PBS incubation solution $(1.5 \mathrm{~mL})$ at a final concentration of 20 $\mu \mathrm{M}$. The cells were incubated in the incubation solution for $45 \mathrm{~min}$ at $37^{\circ} \mathrm{C}$ in an incubator with $5 \% \mathrm{CO}_{2}$ atmosphere. For nuclear staining by DAPI (diluted to $10 \mu \mathrm{g} / \mathrm{mL}$ in PBS), cells were fully immersed in $1 \mathrm{~mL}$ of staining solution and incubated at $37^{\circ} \mathrm{C}$ in an incubator with a $5 \% \mathrm{CO}_{2}$ atmosphere for $15 \mathrm{~min}$. Staining solution was removed from cells, and 4\% paraformaldehyde fixing solution $(1 \mathrm{~mL})$ was added and cells were incubated for $15 \mathrm{~min}$ at 20 to $25^{\circ} \mathrm{C}$ to be fixed, before they were washed 3 times with 1 $\mathrm{mL}$ of PBS for $2-5$ min. Polyvinylpyrrolidone mounting medium $(50 \mu \mathrm{L})$ was added and cells were taken to a confocal microscope for imaging.

Note: incubation time and concentration of the DSNP and substrates were tunable. For membrane staining, DSNP was incubated for 30 min with a concentration of $228 \mathrm{nM}$ in PBS (containing $40 \mu M P d$ ), and the substrate was incubated for 45 min with a concentration of $20 \mu M$ in PBS.

Metal Leakage Kinetics by ICP-MS. A solution of Cu ${ }^{\mathrm{II}}$-DSNP 6 or Pd ${ }^{\mathrm{II}}$-DSNP 12 was placed in a dialysis bag $(\mathrm{MWCO}=1 \mathrm{kDa})$ and was dialyzed against PBS solution containing EDTA in a beaker. Initial concentrations of solutions were listed below:

$\mathrm{Cu}^{\mathrm{II}}$-DSNP 6: $2.6 \mu \mathrm{M}$, containing $300 \mu \mathrm{M}$ of $\mathrm{Cu}(\mathrm{II}), 1.2 \mathrm{~mL}$

Pd $^{\mathrm{II}}$-DSNP 6: $2.6 \mu \mathrm{M}$, containing $300 \mu \mathrm{M}$ of Pd(II), $1.2 \mathrm{~mL}$

EDTA (in PBS): $4.5 \mu \mathrm{M} / 80 \mathrm{~mL}$

(Mole ratio of $\mathrm{Cu}$ and EDTA was 1:1)

Every $45 \mathrm{~min}$, an aliquot of solution in the beaker (outside the dialysis bag) was taken and sent for ICP-MS measurement for respective metal ion content. The experiment 
was repeated three times and the leaked metal amounts were calculated from the measured weight ppb values and were plotted against time.

MTT Cytotoxicity Assay. Considering there is only short, one-time incubation of DSNP with the cells prior to intracellular click, only a short-period cytotoxicity profile was assessed. Cells were treated with serial dilutions of DSNPs in DMEM ranging from 256 to $1 \mu \mathrm{g} / \mathrm{mL}$ (final) and further incubated for $2 \mathrm{~h}$. Cells with no DSNPs added served as controls. After incubation, the old media was removed, and the cells were washed with PBS once before the cell media were replaced with $120 \mu \mathrm{L}$ of fresh media with MTT $(0.5 \mathrm{mg} / \mathrm{mL})$. Cells were incubated for another $1.5 \mathrm{~h}$ at $37{ }^{\circ} \mathrm{C}$. Next, the media were replaced with $100 \mu \mathrm{L}$ of DMSO and cell viability was determined by measuring the absorbance at $595 \mathrm{~nm}$. Cell viability values were expressed as percentages and calculated as follows: Viability $\%=[\operatorname{Abs}(595 \mathrm{~nm})$ of treated sample $) /[\operatorname{Abs}(595 \mathrm{~nm})$ of control] $\times 100 \%$. 


\section{Characterization}

\section{Additional GPC Data}
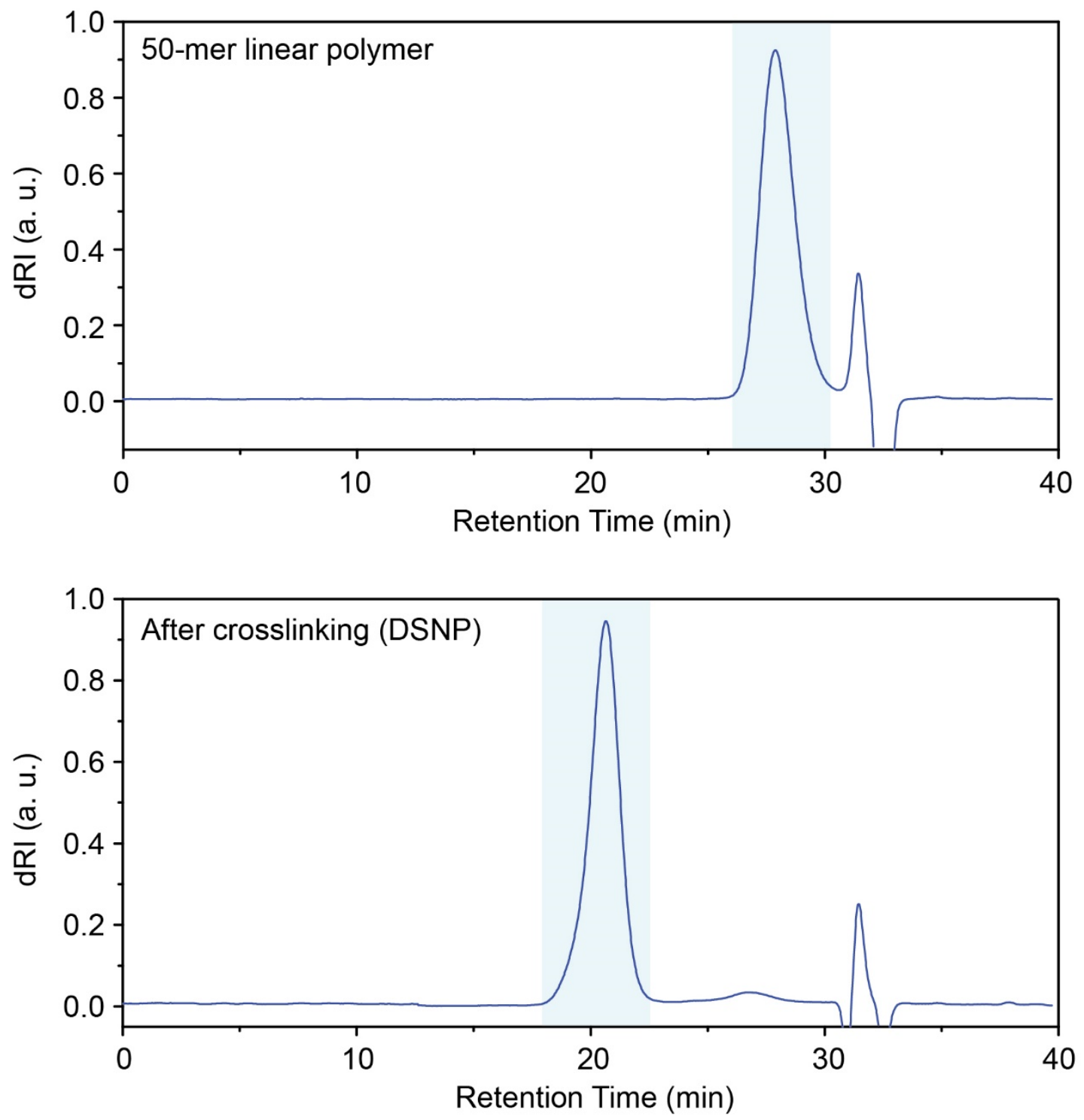

Figure S1. Screenshots of the GPC characterization of polymers. Top: the 50-mer linear polymer before crosslinker was added. $M_{\mathrm{n}}=23.2 \mathrm{kDa}, \mathrm{PDI}=1.03$. Bottom: crosslinked star polymer (DSNP 4). $M_{\mathrm{n}}=1.24 \mathrm{MDa}, \mathrm{PDI}=1.10$. 


\section{Transmission Electron Microscopy (TEM)}
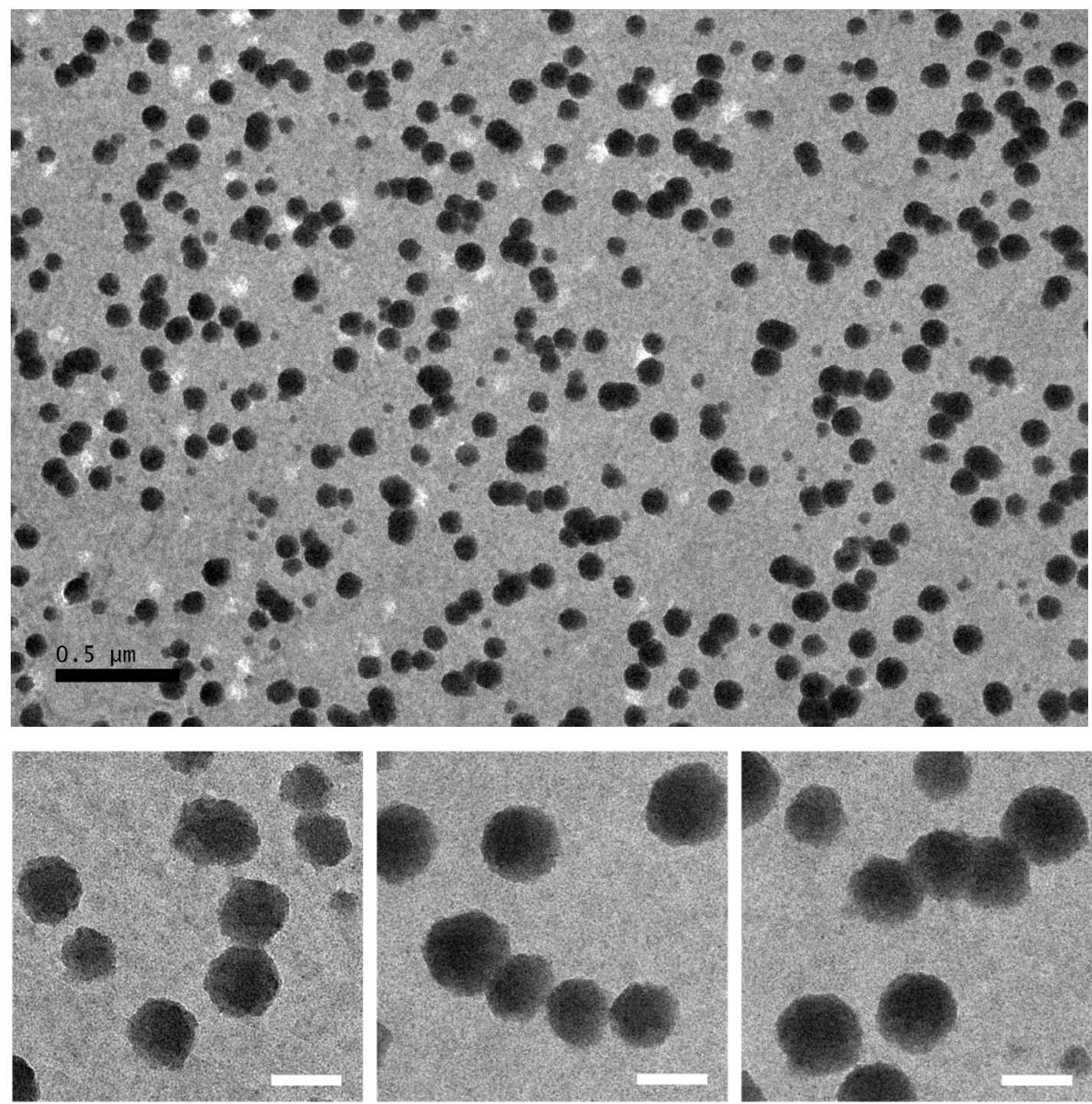

Figure S2. Additional TEM images of the copper-containing polymer scaffold, 6. Scale bar $=500 \mathrm{~nm}$ (top images) or $100 \mathrm{~nm}$ (bottom images). 


\section{$\underline{\text { DLS and Zeta-potential measurement }}$}
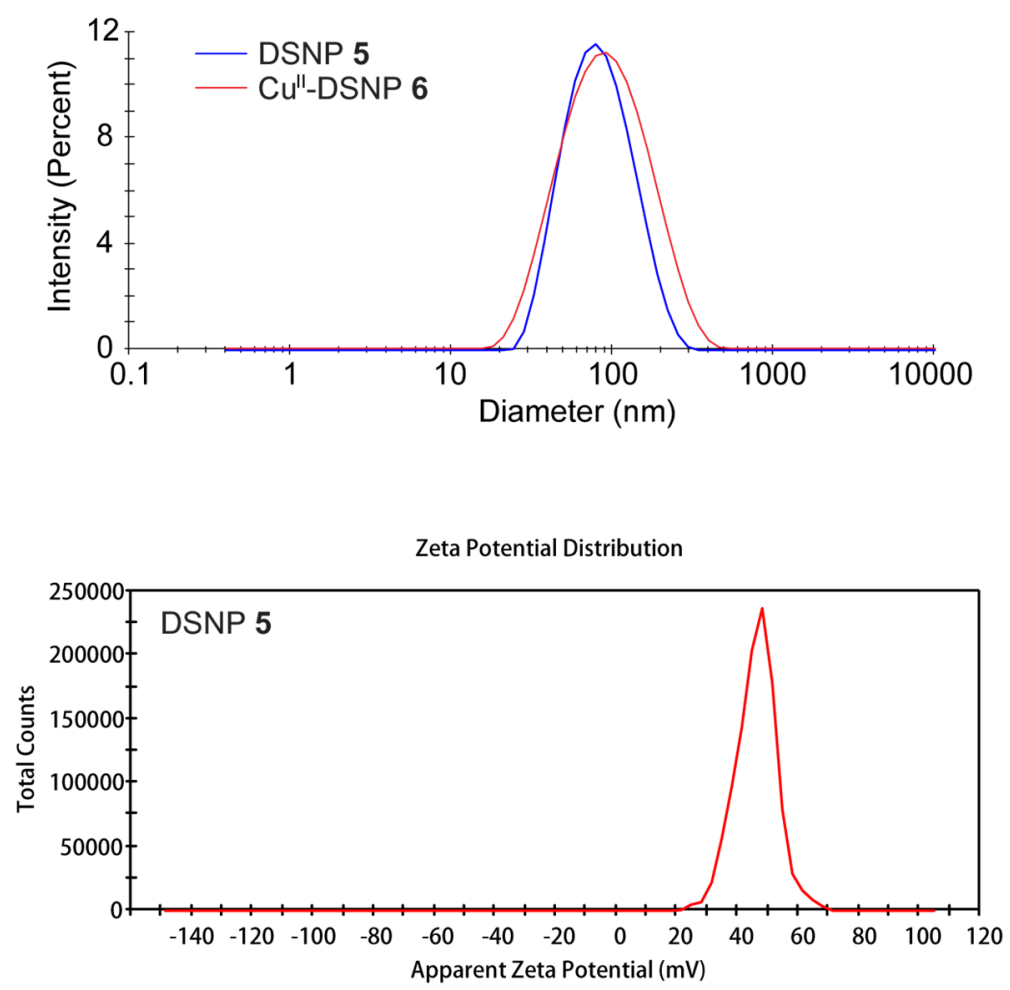

Figure S3. DLS and Zeta-potential measurement result of the DSNPs.

Zeta-potential measurement of DSNP (5) in ultra-pure water showed a zeta-potential of $+45.6 \pm 3.0 \mathrm{mV}$, indicating that the polymeric nanoparticle is highly and positively charged. This is a natural consequence of the quaternization of the polymer by $\mathrm{N}$ butylimidazole, affording imidazolium moieties with permanent positive charges. Measurement of $\mathrm{Cu}^{\mathrm{II}}$-DSNP (6) showed almost identical result. 
NMR Characterization of Intermediates and Polymers
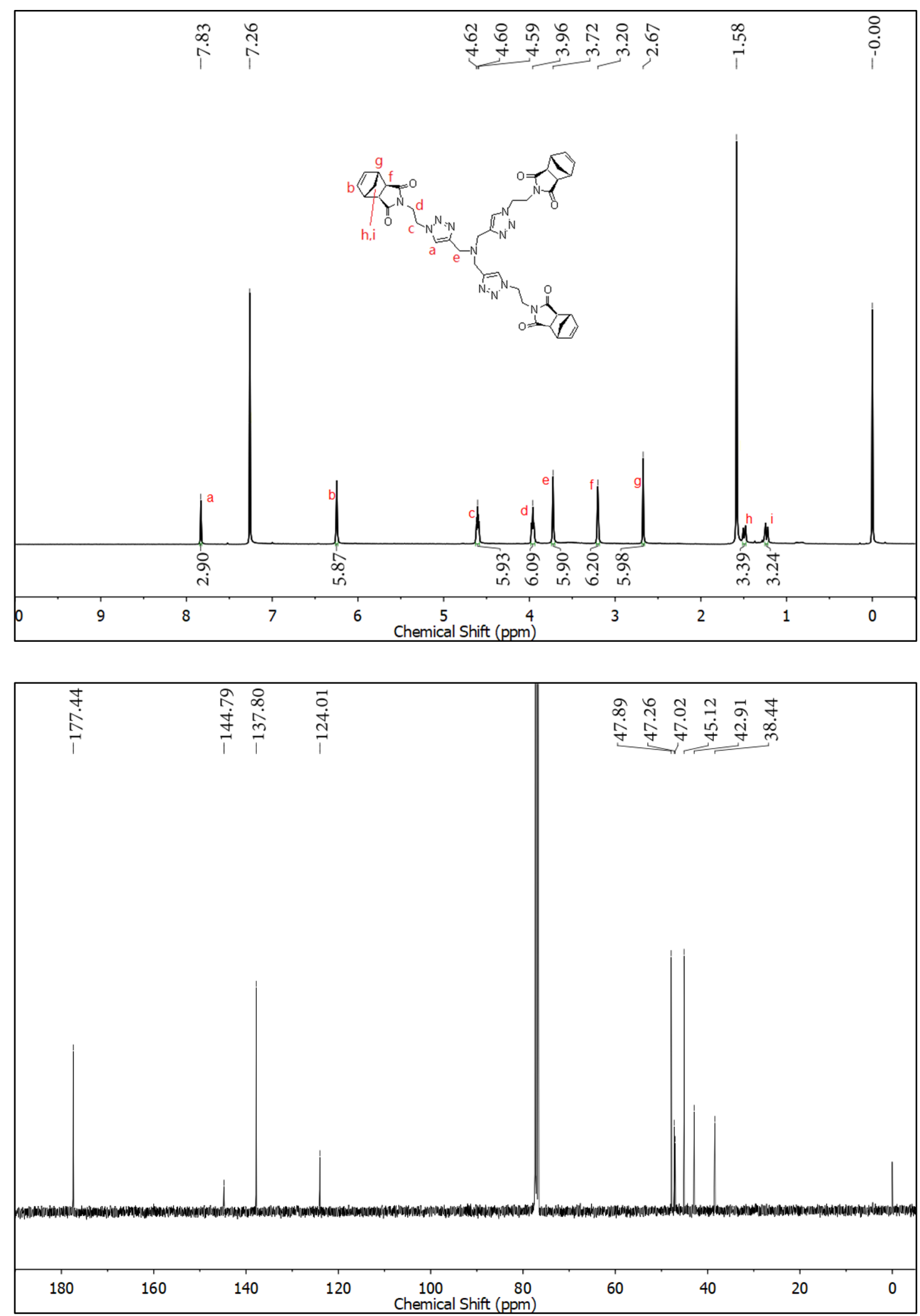

Figure S4. ${ }^{1} \mathrm{H}$ (top) and ${ }^{13} \mathrm{C}$ (bottom) NMR characterization of crosslinker 3 in $\mathrm{CDCl}_{3}$. 


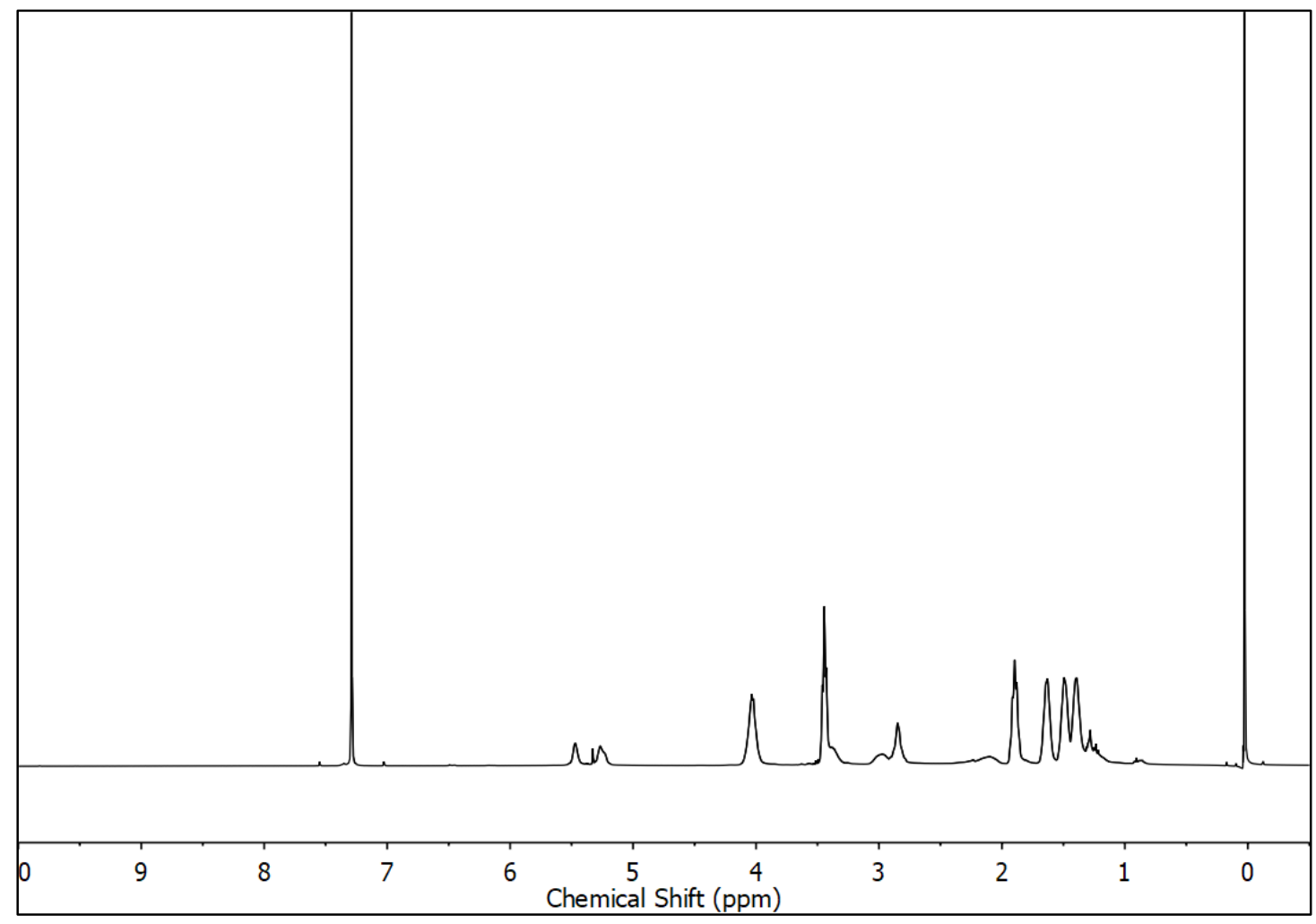

Figure S5. ${ }^{1} \mathrm{H}$ NMR characterization of DSNP 4 in $\mathrm{CDCl}_{3}$.

The core (tris-triazole crosslinker residues) was not observed on ${ }^{1} \mathrm{H} \mathrm{NMR}$, despite crosslinking was apparent on GPC analysis, and the successful CuAAC catalysis. This is not surprising, as the core is highly crosslinked and has no or very little mobility (like a solid). In this case, anisotropic interactions have a substantial influence of nuclear spins, making the corresponding spins invisible on the spectrum. 


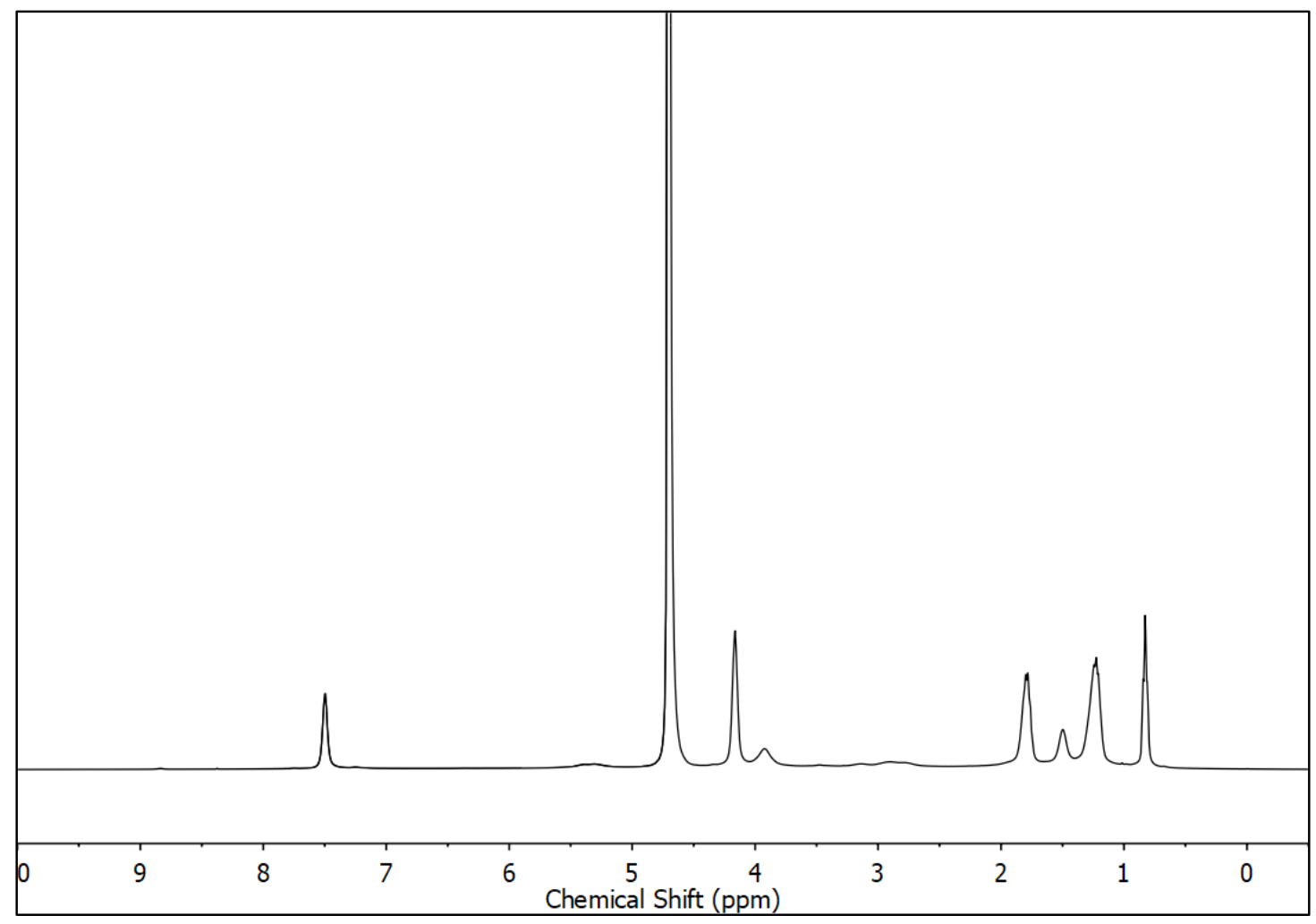

Figure S6. ${ }^{1} \mathrm{H}$ NMR characterization of DSNP 5 in $\mathrm{D}_{2} \mathrm{O}$.

The core (tris-triazole crosslinker residues) was not observed on ${ }^{1} \mathrm{H}$ NMR for the same reason as above (see notes below Figure S5). In addition, protons on C2 position of imidazolium was not seen. This was because of the deuterium exchange in $\mathrm{D}_{2} \mathrm{O}$, as this proton on $\mathrm{C} 2$ is slightly acidic and was reported to exchange with deuterium. ${ }^{[9]}$ 
$\underline{\text { NMR Analysis of the CuAAC Reactions }}$

Table S1. "Click" reactions of various azides and alkynes with $\mathrm{Cu}$-DSNP 7 (same as Table 1 in the main text).

\begin{tabular}{|c|c|c|c|c|c|}
\hline Entry & Alkyne & Azide & $\begin{array}{c}\mathrm{Cu}^{\mathrm{I}-} \\
\text { DSNP } \\
\text { level } \\
(\mathrm{ppm})\end{array}$ & $\begin{array}{c}\mathrm{Cu} \\
\text { level } \\
(\mathrm{ppm})\end{array}$ & $\begin{array}{c}\text { NMR } \\
\text { yield } \\
(\%)\end{array}$ \\
\hline 1 & & & 0.43 & 50 & $>99$ \\
\hline 2 & & & 0.43 & 50 & 98 \\
\hline 3 & & & 0.86 & 100 & $>99$ \\
\hline 4 & & & 0.86 & 100 & 92 \\
\hline 5 & & & 0.86 & 100 & 96 \\
\hline 6 & & & 1.28 & 150 & $>99$ \\
\hline 7 & & & 1.28 & 150 & 86 \\
\hline 8 & & & 0.86 & 100 & 96 \\
\hline 9 & & & 0.86 & 100 & 93 \\
\hline 10 & & & 1.72 & 200 & 88 \\
\hline 11 & & & 1.28 & 150 & $>99$ \\
\hline
\end{tabular}

Note: for Entry 10, 0.30 mmol of alkyne was used in the experiment. Details of the used substrates are given in the next page. 


\section{Substrates used:}

Phenylpropyl azide and 1-azidodecane. Syntheses and characterization of these two compounds are described in Fer, M. J.; Olatunji, S.; Bouhss, A.; Calvet-Vitale, S.; Gravier-Pelletier, C. J. Org. Chem. 2013, 78, 10088.

Benzyl azide and 2,4,6-trimethylbenzyl azide. Syntheses of these two compounds are described in Bai, Y.; Feng, X.; Xing, H.; Xu, Y.; Kim, B. K.; Baig, N.; Zhou, T.; Gewirth, A. A.; Lu, Y.; Oldfield, E.; Zimmerman, S. C. J. Am. Chem. Soc. 2016, 138, 11077.

Ethyl 5-azidovalerate. Synthesis and characterization of this compound is described in Fricke, T., Mart, R. J.; Watkins, C. L.; Wiltshire, M.; Errington, R. J.; Smith, P. J.; Jones, A. T.; Allemann, R. K. Bioconjugate Chem. 2011, 22, 1763.

Phenylacetylene, propargyl acetate, 4-ethynyltoluene, 4-ethynylanisole. These compounds were purchased directly from a commercial source and used without further purification (see Materials section of this supporting document).

Characterization of the crude and purified products. For all the reactions tested, after $\mathrm{CDCl}_{3} /$ water partitioning, no major by-products could be observed by ${ }^{1} \mathrm{H}$ NMR spectroscopy. Only the desired products and the unreacted starting materials (if any), with a trace amount of unknown impurity peaks could be seen on the NMR spectra. Since most of the product compounds have been previously reported, ${ }^{1} \mathrm{H}$ NMR spectra of the crude compounds were shown to show the efficiency and cleanness of the DSNPcatalyzed reactions, and the previous reports of each known compounds were also listed for reference. One ${ }^{1} \mathrm{H}$ NMR spectrum of the pure compound (from Entry 1) are given to show the easy work-up of the catalyzed reactions. 


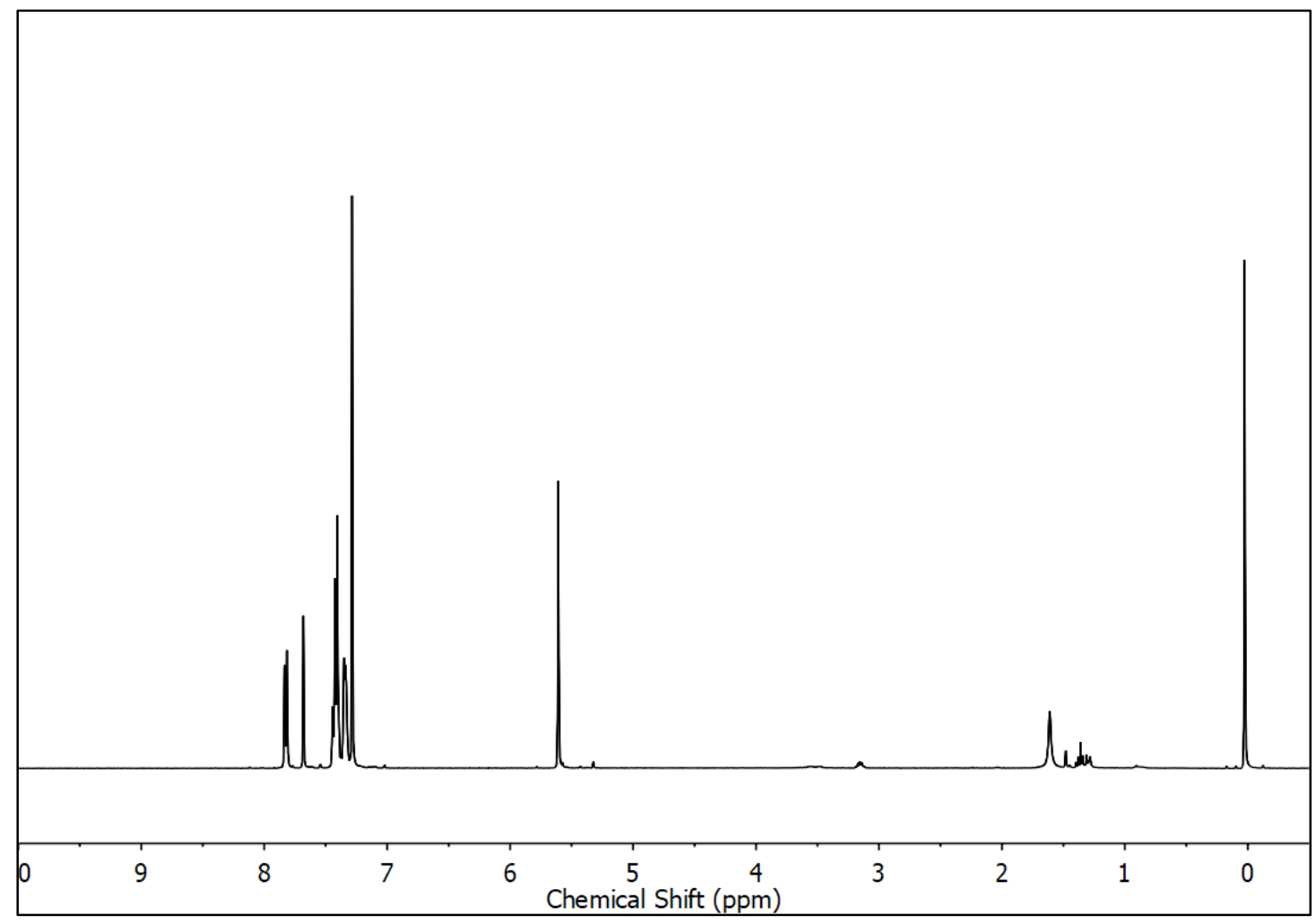

Figure S7. Crude (direct from the $\mathrm{CDCl}_{3}$ extracts) product from the reaction of phenylacetylene and benzyl azide in Entry 1, Table S1.

Characterization of the purified product has been reported in Deraedt, C.; Pinaud, N.; Astruc, D. J. Am. Chem. Soc. 2014, 136, 12092. 


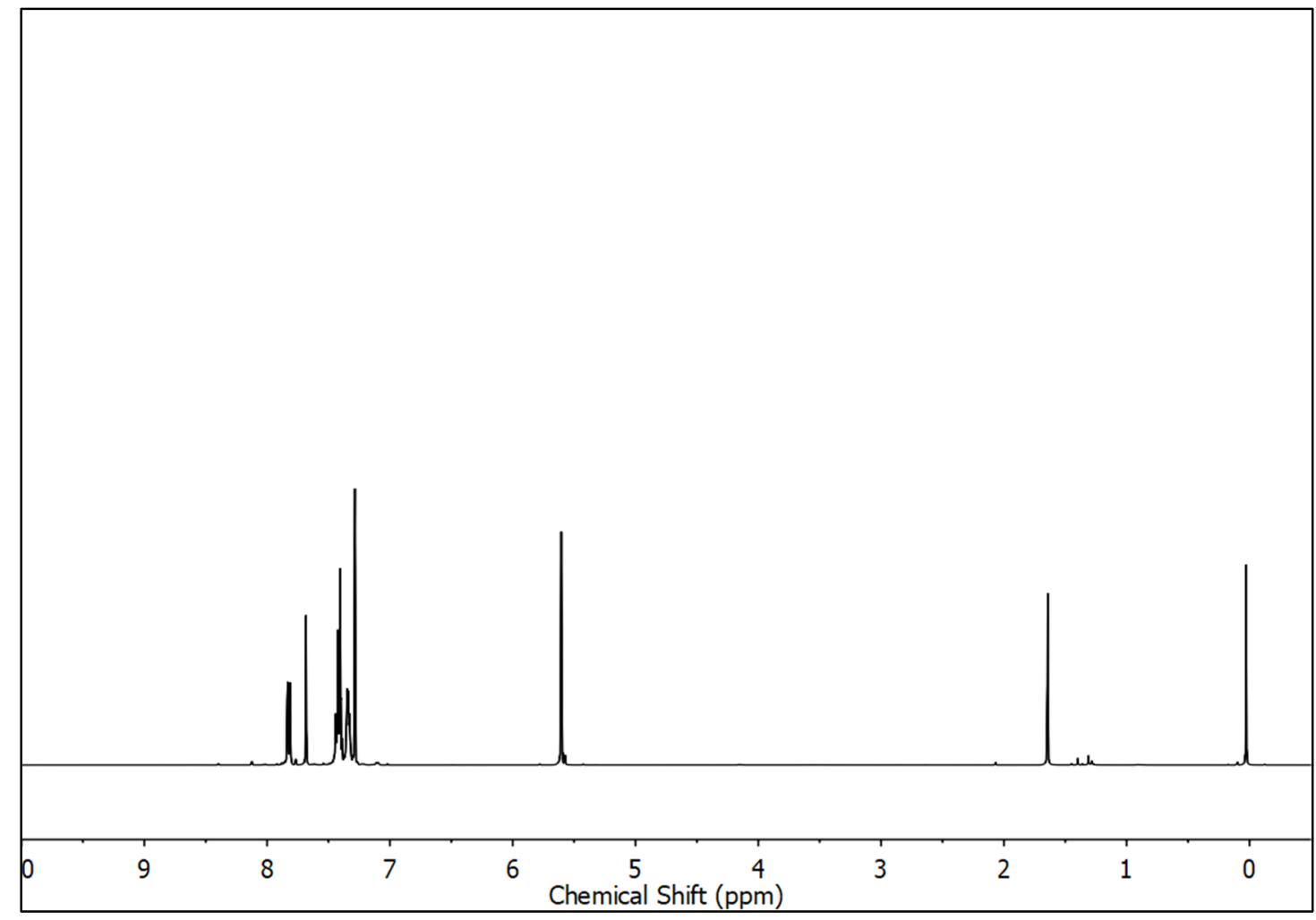

Figure S8. Purified product (after flash column chromatography) from the reaction in Entry 1, Table S1. Isolated yield: 92\%. 


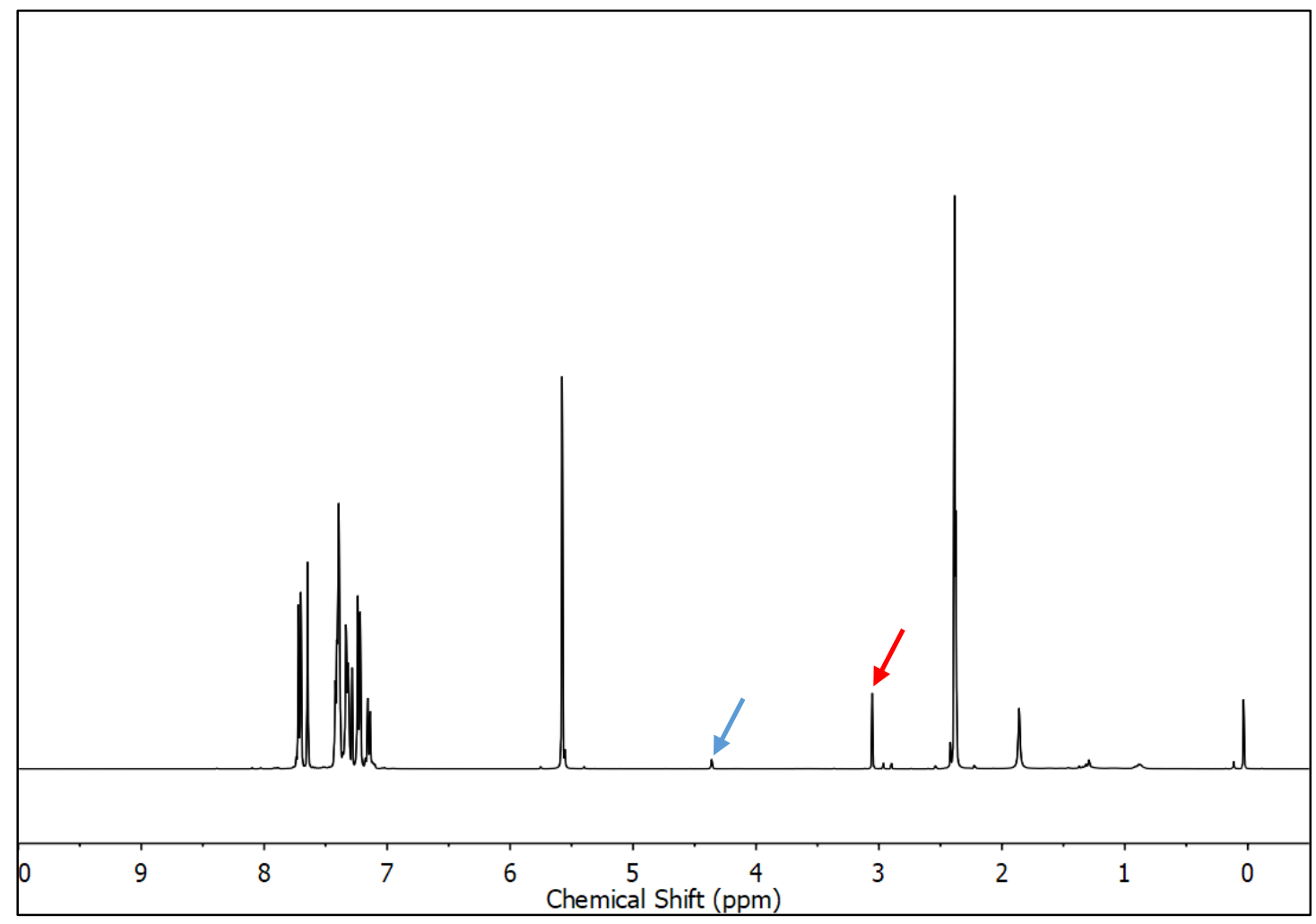

Figure S9. Crude (direct from the $\mathrm{CDCl}_{3}$ extracts) product from the reaction of 4 ethynyltoluene and benzyl azide in Entry 2, Table S1. Red and blue arrows mark the peaks of the unreacted azide and alkyne substrates, respectively.

Characterization of the purified product has been reported in Yamada, Y. M. A.; Sarkar, S. M.; Uozumi, Y. J. Am. Chem. Soc. 2012, 134, 9285. 


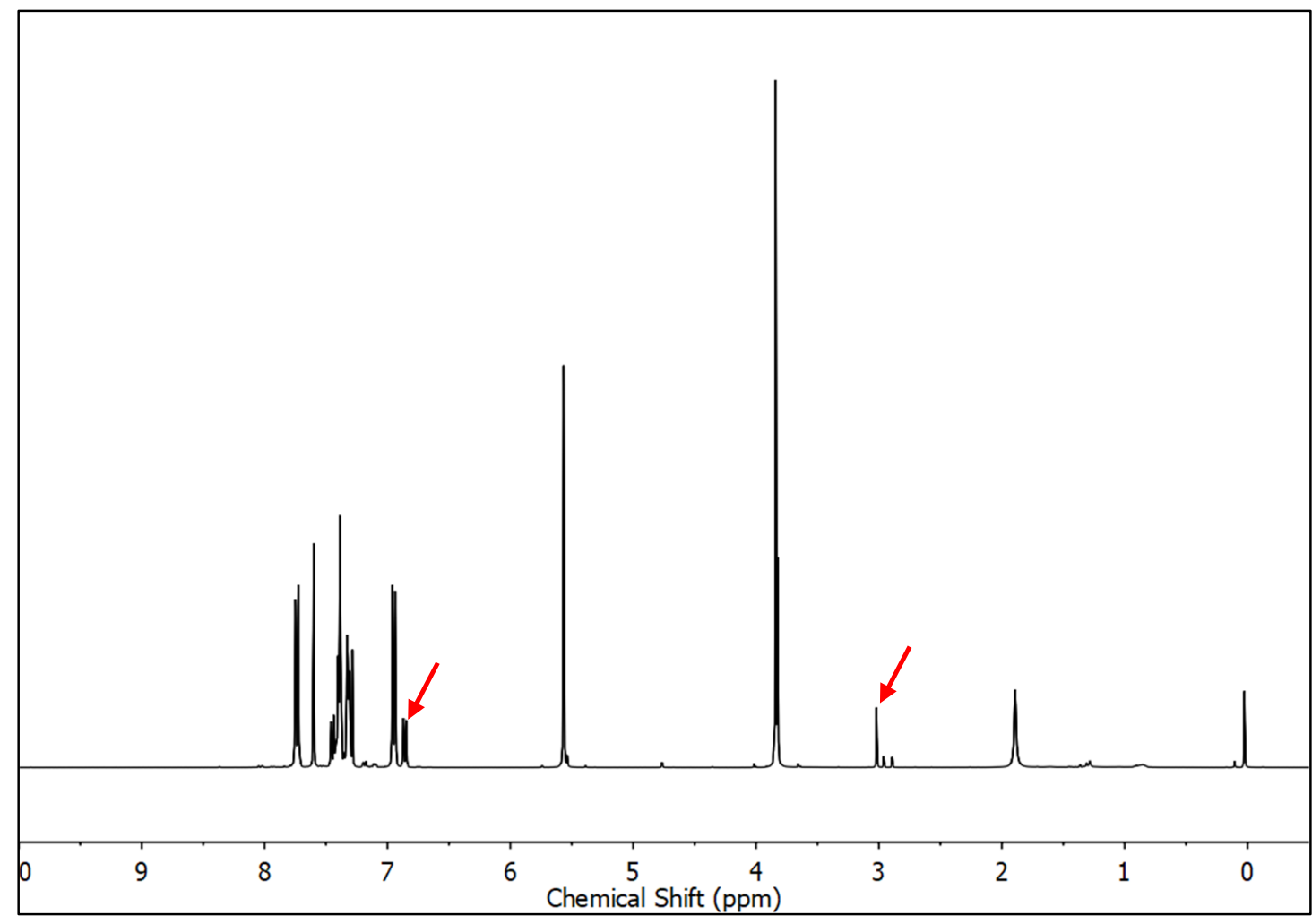

Figure S10. Crude (direct from the $\mathrm{CDCl}_{3}$ extracts) product from the reaction of 4ethynylanisole and benzyl azide in Entry 3, Table S1. Red arrows mark the peaks of the unreacted alkyne substrate (excess).

Characterization of the purified product has been reported in Topchiy, M. A.; Ageshina, A. A.; Gribanov, P. S.; Masoud, S. M.; Akmalov, T. R.; Nefedov, S. E.; Osipov, S. N.; Nechaev, M. S.; Asachenko, A. F. Eur. J. Org. Chem. 2019, 2019, 1016. 


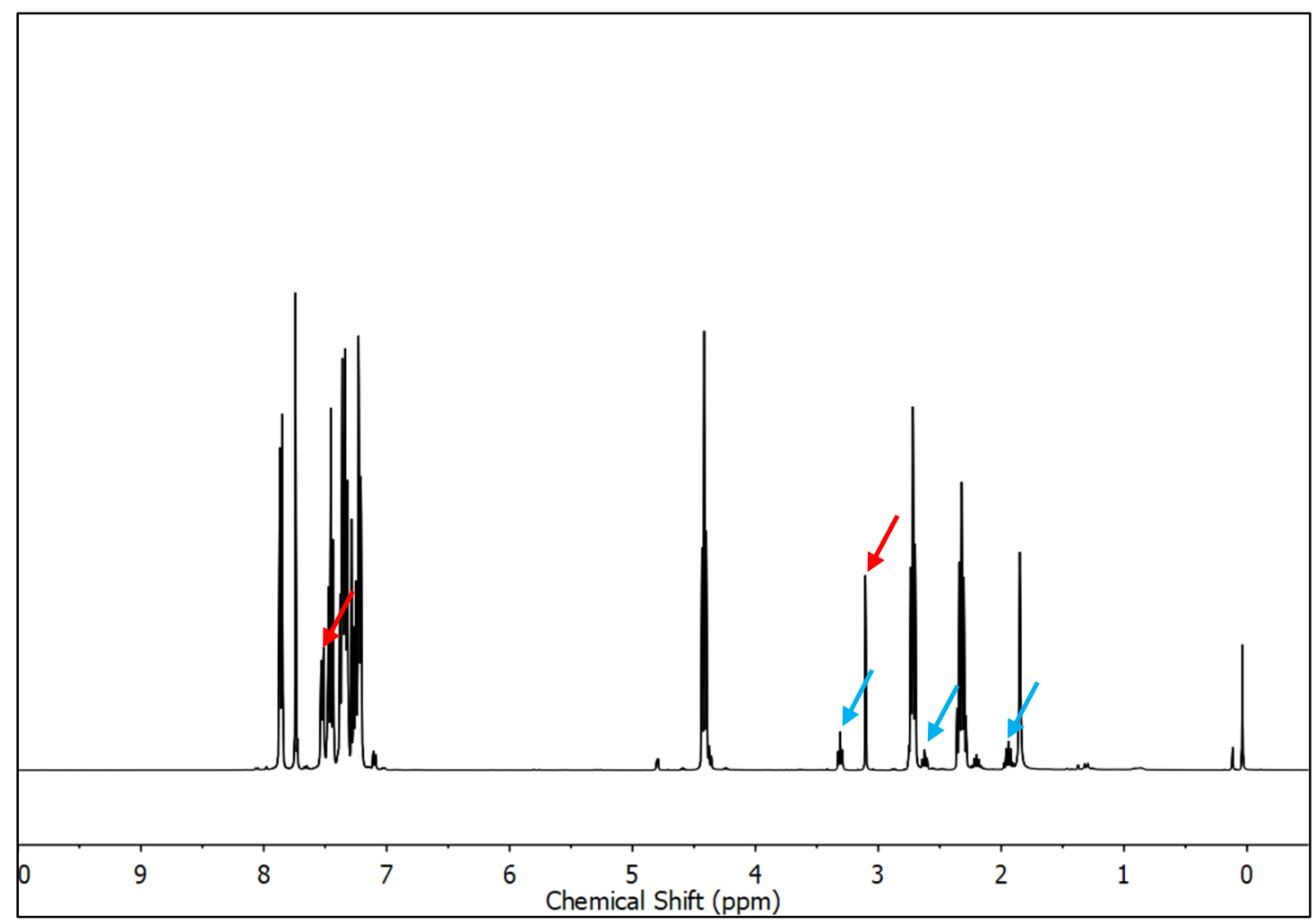

Figure S11. Crude (direct from the $\mathrm{CDCl}_{3}$ extracts) product from the reaction of phenylacetylene and phenylpropyl azide in Entry 4, Table S1. Blue and red arrows mark the peaks of the unreacted azide and alkyne substrates.

Characterization of the purified product has been reported in Shin, J.-A.; Lim, Y.-G.; Lee, K.-H. J. Org. Chem. 2012, 77, 4117. 


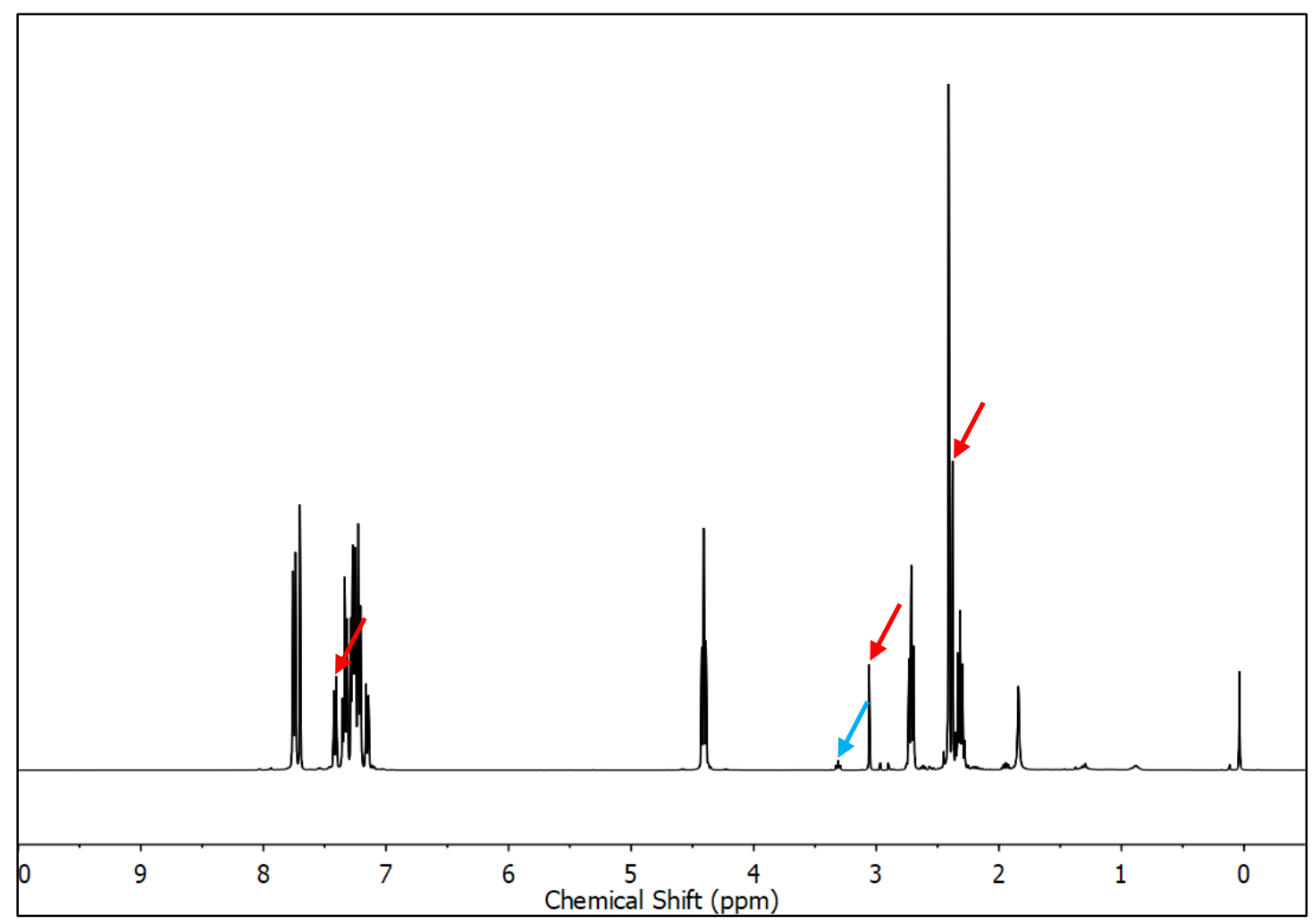

Figure S12. Crude (direct from the $\mathrm{CDCl}_{3}$ extracts) product from the reaction of 4ethynyltoluene and phenylpropyl azide in Entry 5, Table S1. Blue and red arrows mark the peaks of the unreacted azide and alkyne substrates.

This compound has not been previously reported. Characterization data of the purified compound is listed below:

${ }^{1} \mathrm{H}$ NMR (400 MHz, $\left.\mathrm{CDCl}_{3}\right): \delta 7.71(d, J=7.9 \mathrm{~Hz}, 2 \mathrm{H}), 7.66(\mathrm{~s}, 1 \mathrm{H}), 7.16-7.33(\mathrm{~m}$, $7 \mathrm{H}), 4.37(t, J=7.1 \mathrm{~Hz}, 2 \mathrm{H}), 2.68(t, J=7.5 \mathrm{~Hz}, 2 \mathrm{H}), 2.37(\mathrm{~s}, 3 \mathrm{H}), 2.28(m, 2 \mathrm{H})$.

${ }^{13} \mathrm{C}$ NMR (100 MHz, $\left.\mathrm{CDCl}_{3}\right): \delta 147.8,140.2,137.9,129.5,128.6,128.4,127.9,126.4$, $125.6,119.2,49.5,32.5,31.7,21.3$.

High-resolution ESI-MS: calculated for $\mathrm{C}_{18} \mathrm{H}_{20} \mathrm{~N}_{3}{ }^{+}\left([\mathrm{M}+\mathrm{H}]^{+}\right)$: 278.1657, obtained $278.1660\left([\mathrm{M}+\mathrm{H}]^{+}\right)$ 


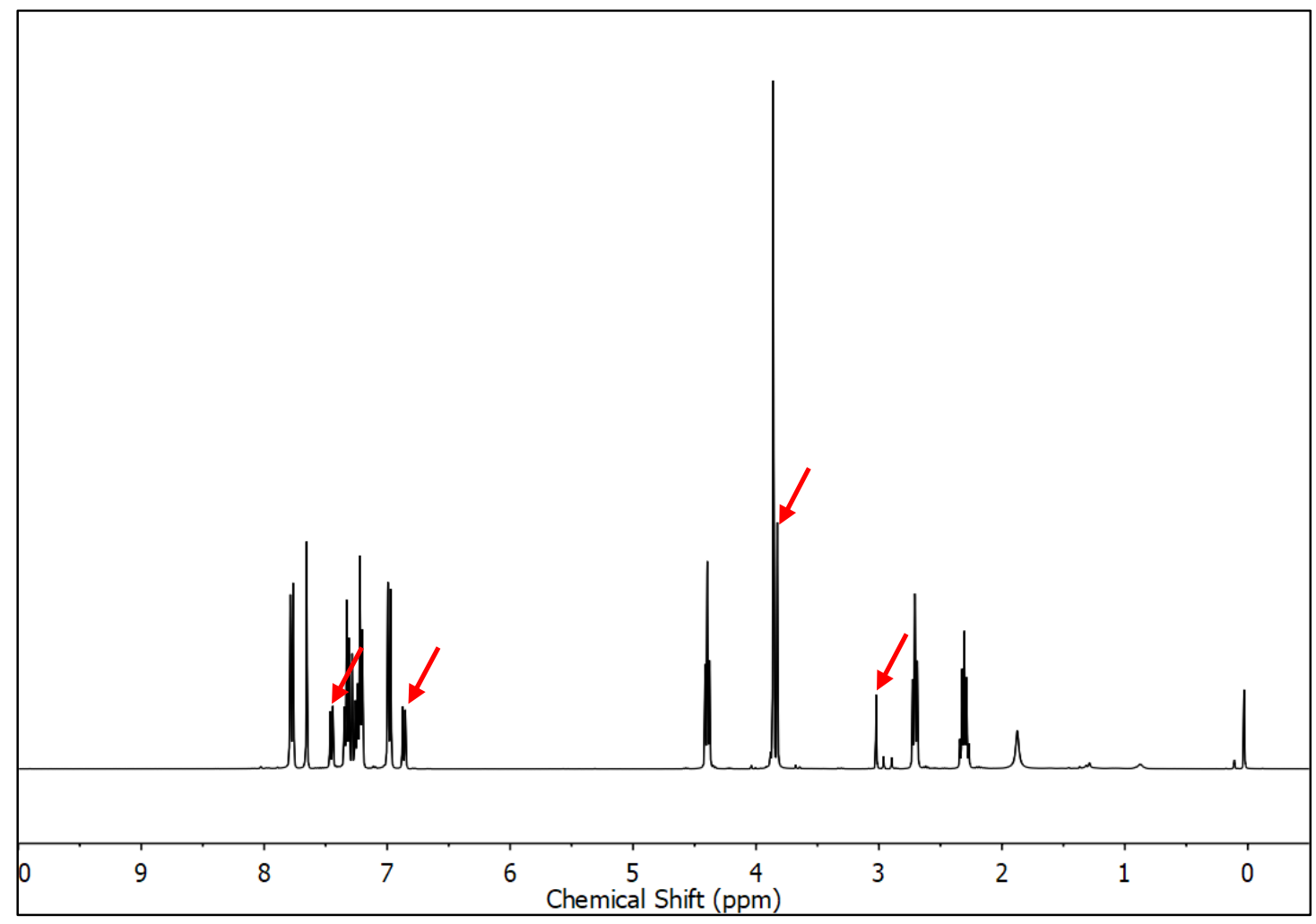

Figure S13. Crude (direct from the $\mathrm{CDCl}_{3}$ extracts) product from the reaction of 4ethynylanisole and phenylpropyl azide in Entry 6, Table S1. Red arrows mark the peaks of the unreacted alkyne substrate (excess).

Characterization of the purified product has been reported in Song, J. H.; Choi, P.; Lee, S. E.; Jeong, K. H.; Kim, T.; Kang, K. S.; Choi, Y. S.; Ham, J. Eur. J. Org. Chem. 2013, $2013,6249$. 


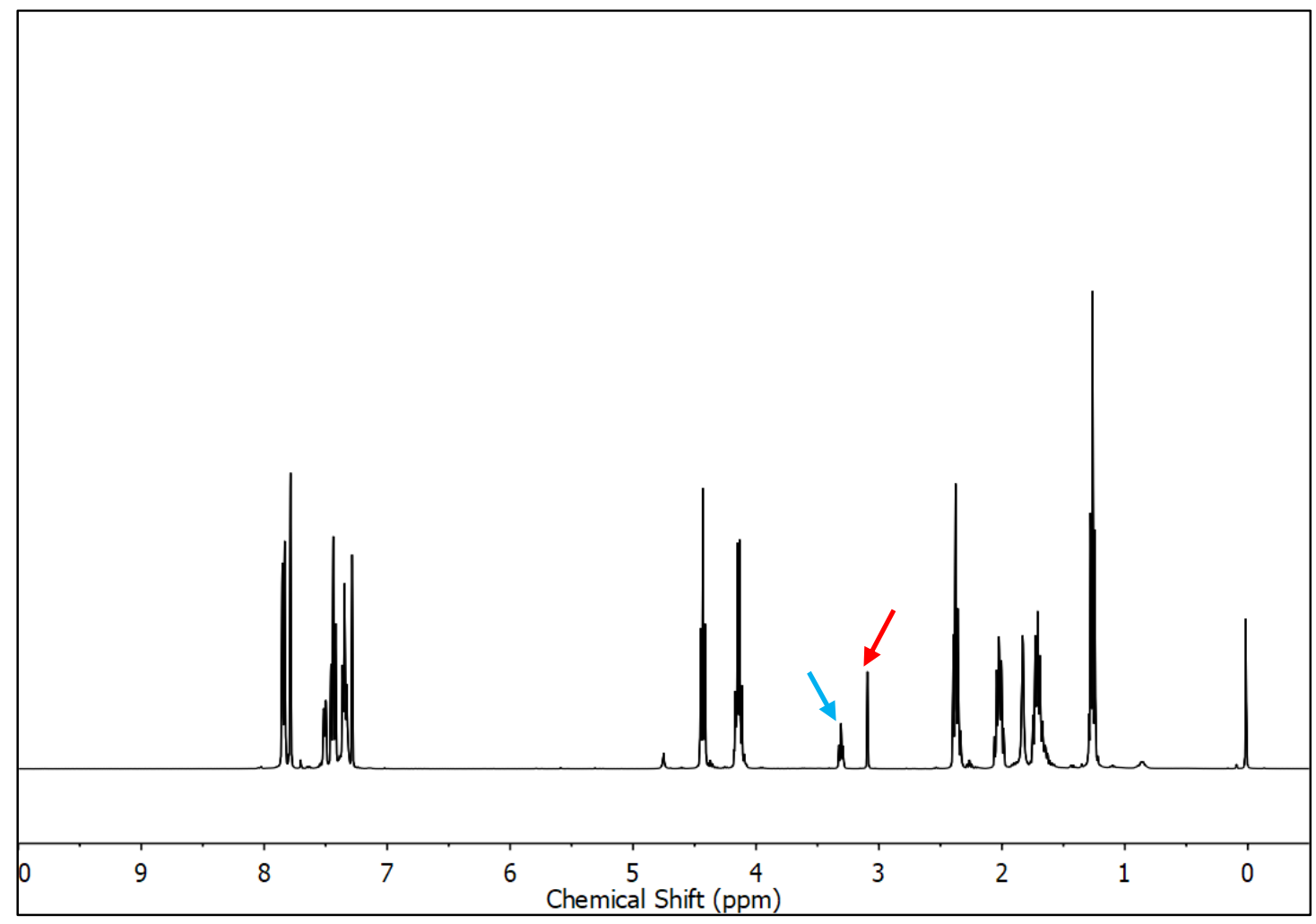

Figure S14. Crude (direct from the $\mathrm{CDCl}_{3}$ extracts) product from the reaction of phenylacetylene and ethyl 5-azidovalerate in Entry 7, Table S1. Blue and red arrows mark the peaks of the unreacted azide and alkyne substrates.

Characterization of the purified product has been reported in Kovács, S.; Zih-Perényi, K.; Révész, A.; Novák, Z. Synthesis 2012, 44, 3722. 


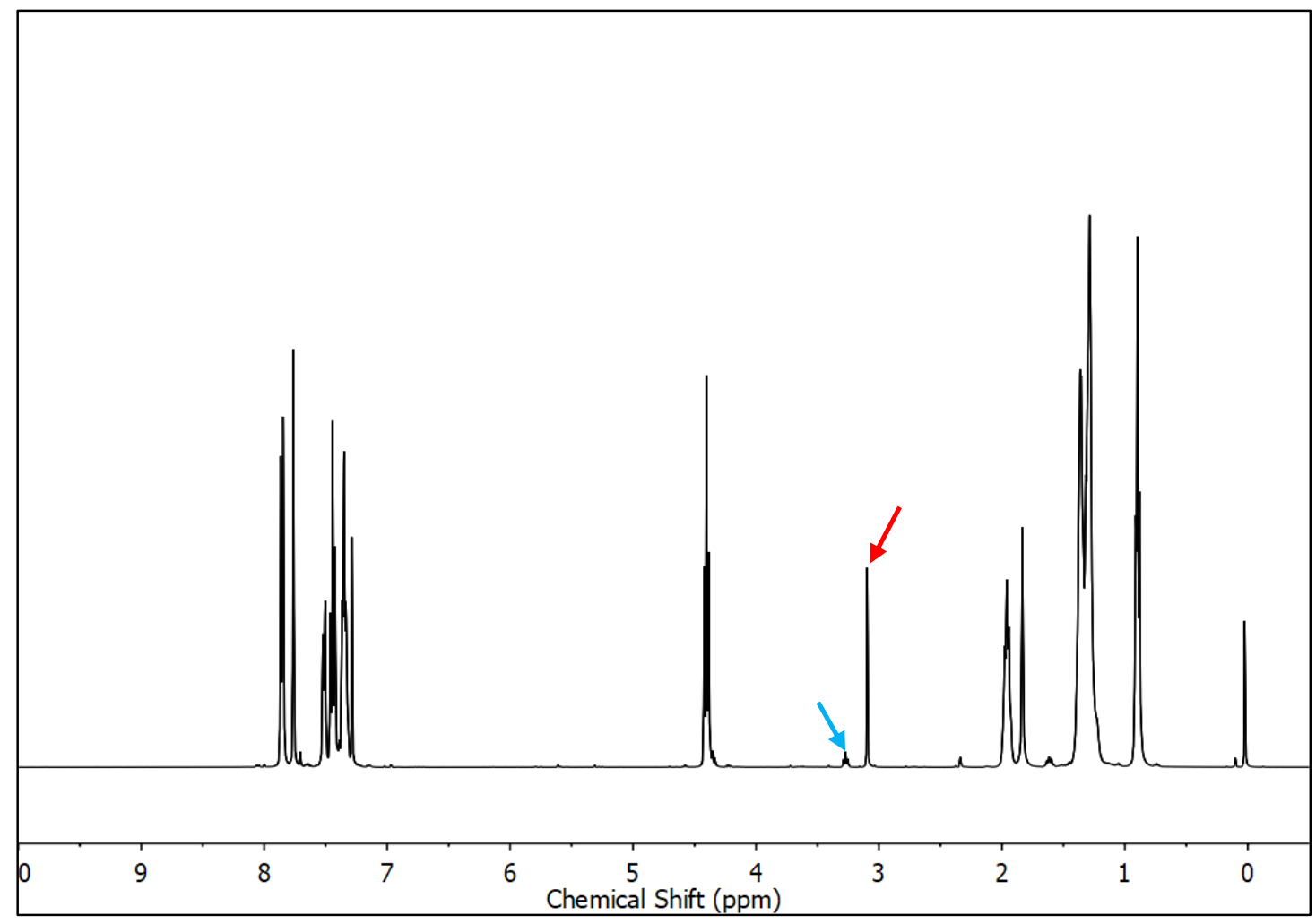

Figure S15. Crude (direct from the $\mathrm{CDCl}_{3}$ extracts) product from the reaction of phenylacetylene and 1-azidooctane in Entry 8, Table S1. Blue and red arrows mark the peaks of the unreacted azide and alkyne substrates.

Characterization of the purified product has been reported in Lai, B.; Mei, F.; Gu, Y. Chem. Asian J. 2018, 13, 2529. 


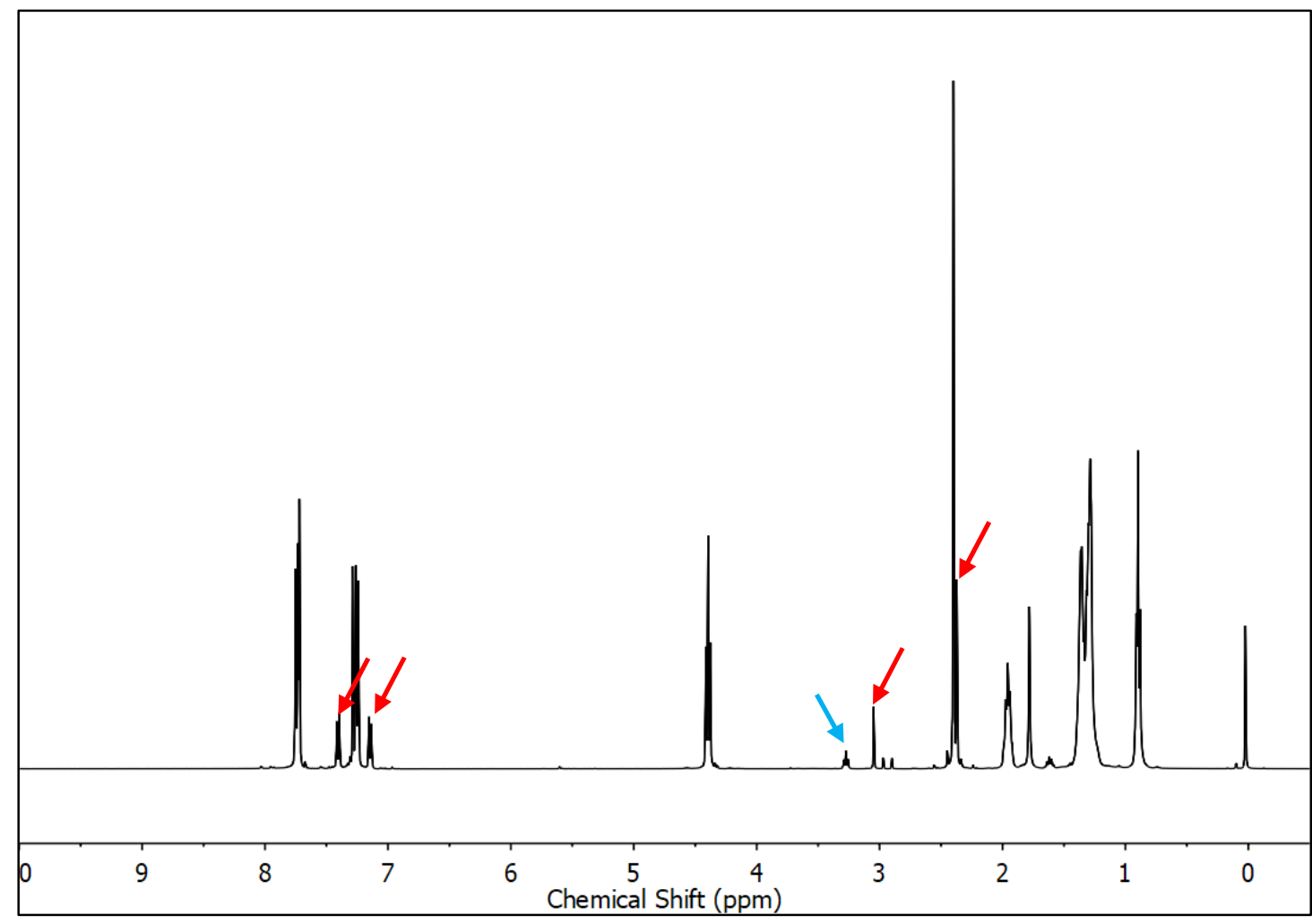

Figure S16. Crude (direct from the $\mathrm{CDCl}_{3}$ extracts) product from the reaction of 4ethynyltoluene and 1-azidooctane in Entry 9, Table S1. Blue and red arrows mark the peaks of the unreacted azide and alkyne substrates.

Characterization of the purified product has been reported in Jia, X.; Xu, G.; Du, Z.; Fu, Y. Polyhedron 2018, 151, 515. 


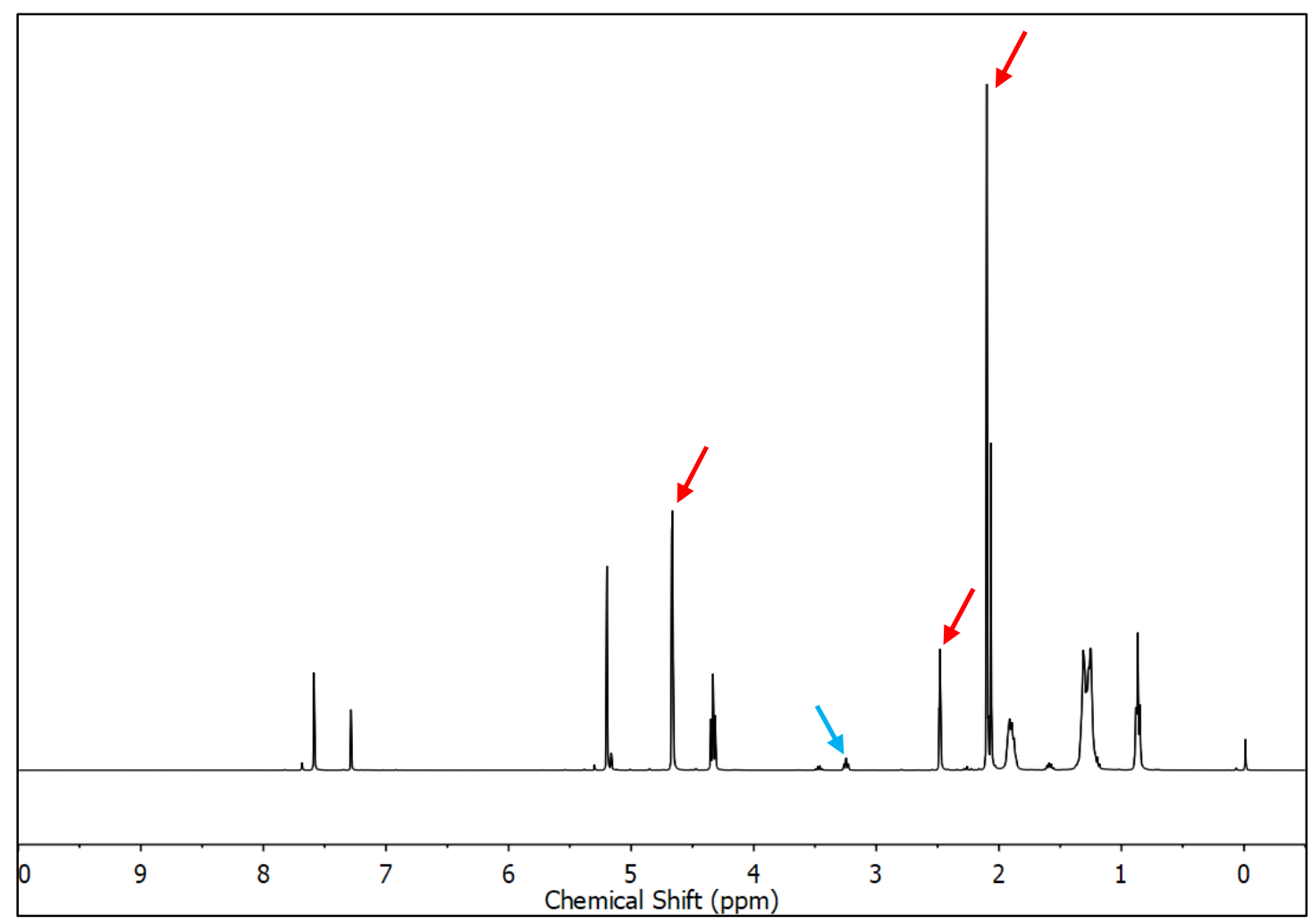

Figure S17. Crude (direct from the $\mathrm{CDCl}_{3}$ extracts) product from the reaction of propargyl acetate and 1-azidooctane in Entry 10, Table S1. Blue and red arrows mark the peaks of the unreacted azide and alkyne substrates. Note: in this experiment, propargyl acetate was in large excess.

This compound has not been previously reported. Characterization data of the purified compound is listed below:

${ }^{1} \mathrm{H}$ NMR (400 MHz, $\left.\mathrm{CDCl}_{3}\right): \delta 7.59(s, 1 \mathrm{H}), 5.20(s, 2 \mathrm{H}), 4.33(t, J=7.3 \mathrm{~Hz}, 2 \mathrm{H}), 2.48$ (broad, 2H), $2.07(s, 3 \mathrm{H}), 1.90$ (broad, 2H), 1.21-1.35 (broad m, 10H), $0.87(t, J=6.6$ $\mathrm{Hz}, 3 \mathrm{H})$.

${ }^{13} \mathrm{C} \mathrm{NMR}\left(100 \mathrm{MHz}, \mathrm{CDCl}_{3}\right): \delta 170.9,142.8,123.5,57.7,50.4,31.7,30.3,29.0,28.9$, $26.5,22.6,20.9,14.0$.

High-resolution ESI-MS: calculated for $\mathrm{C}_{13} \mathrm{H}_{23} \mathrm{~N}_{3} \mathrm{O}_{2} \mathrm{Na}: 276.1688\left([\mathrm{M}+\mathrm{Na}]^{+}\right)$, obtained $276.1688\left([\mathrm{M}+\mathrm{Na}]^{+}\right)$. 


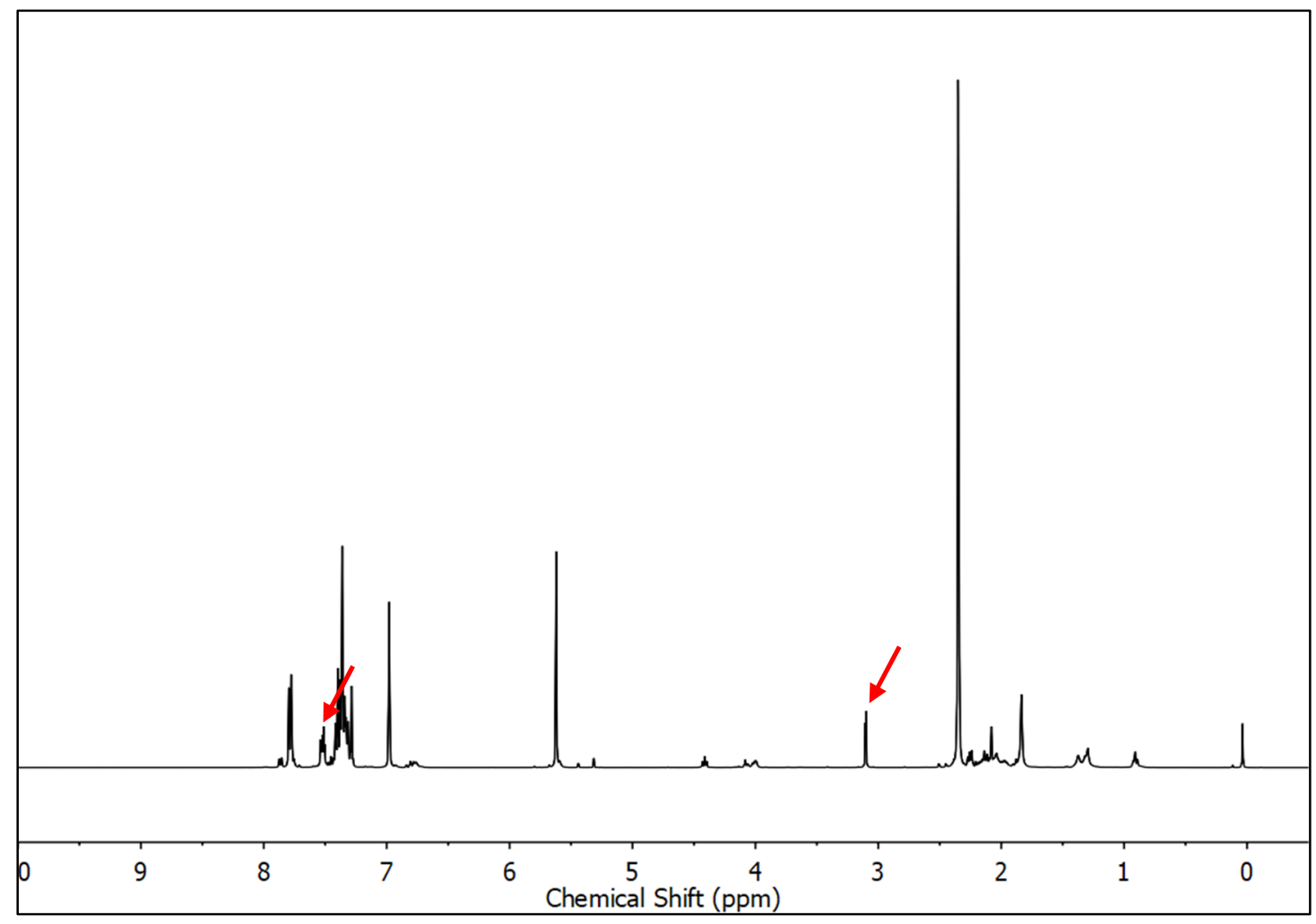

Figure S18. Crude (direct from the $\mathrm{CDCl}_{3}$ extracts) product from the reaction of phenylacetylene and 2,4,6-trimethylbenzyl azide in Entry 11, Table S1. Red arrows mark the peaks of the unreacted alkyne substrate (excess).

Characterization of the purified product has been reported in Bagh, B.; McKinty, A. M.; Lough, A. J.; Stephan, D. W. Dalton Trans. 2014, 43, 12842. 


\section{$\underline{\text { Additional Kinetics Study }}$}

(a)

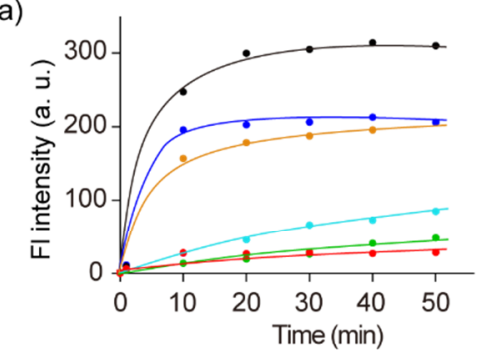

$\rightarrow 1 \% \mathrm{FBS} \rightarrow 1 \%$ Cell lysate $\rightarrow 25 \%$ DMEM

$\rightarrow 5 \%$ FBS $\rightarrow 5 \%$ Cell lysate $\rightarrow 70 \mu$ M EDTA (b)

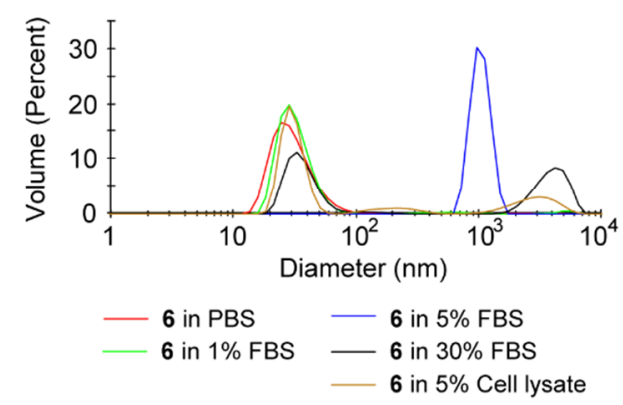

Figure S19. (a) Kinetics of the reaction between $8(20 \mu \mathrm{M})$ and $9(40 \mu \mathrm{M})$ in different media, using 7 (860 nM) as catalyst. (b) DLS characterization of 6 in different media (7 and $\mathbf{1 2}$ behave similarly as the scaffold determines the behavior).

Note S1. In Figure $2 \mathrm{~d}, \mathrm{Pd}(\mathrm{OAc})_{2}$ catalyzed reaction also showed a good initial rate, although it is slower than Pd-DSNP 12. The catalysis stopped in a while and the fluorescence started to go down. We had repeated this experiment and were sure that this was not an artifact, at least at our testing condition. We speculate that this may be a result of $\mathrm{Pd}(\mathrm{OAc})_{2}$ 's hydrolysis, leading to catalyst deactivation and absorption of unmasked rhodamine on the hydrolyzed palladium species. Black species could be observed on glass vial wall for $\mathrm{Pd}(\mathrm{OAc})_{2}$ catalyzed reaction after some time, but we had no more solid evidence for our speculation. This result could anyway show the stabilization effect of the DSNP scaffold. 


\section{$\underline{\text { ICP-MS Analysis of } \mathrm{Cu} \text { and Pd Leakage }}$}

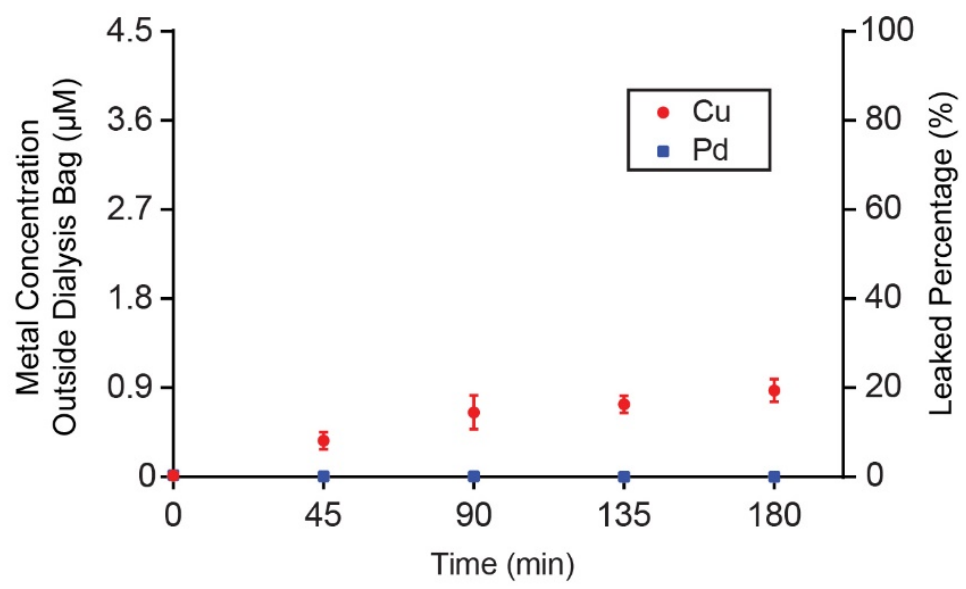

Figure S20. ICP-MS analysis result of metal leakage experiments. The protocol for this experiment can be found in the earlier part of this document. 


\section{Pyrene Uptake Study}

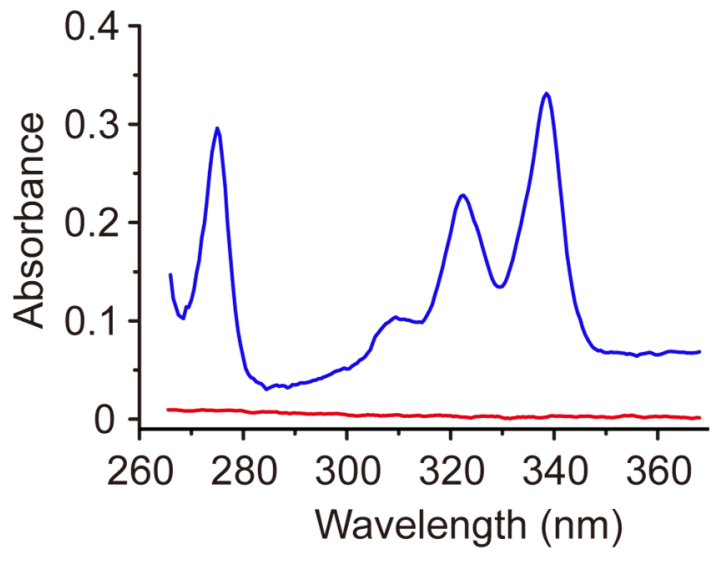

Figure S21. Result of the pyrene uptake study using $6(1.7 \mu \mathrm{M})$ in PBS. With the aid of the DSNP scaffold, pyrene can be "dissolved" in aqueous solution and show strong UV absorbance, presumably because of the scaffold's uptake of water-insoluble pyrene molecules into its hydrophobic pockets. 


\section{$\underline{\text { Additional Confocal Microscope Images }}$}

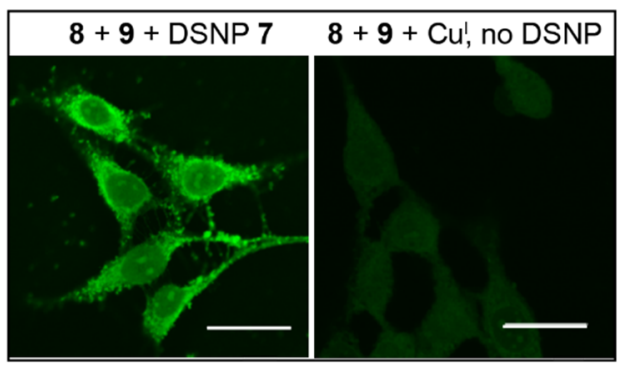

Figure S22. Confocal microscope images of intracellular product formation promoted by the $\mathrm{Cu}^{\mathrm{I}}$-DSNP 7. Without the addition of DSNP scaffold, only very weak fluorescence could be observed, presumably from the residual fluorescence of $\mathbf{8}$. Scale bar $=20 \mu \mathrm{m}$.

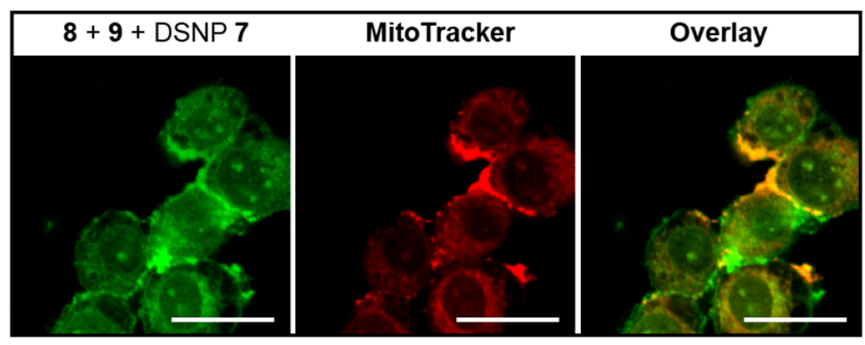

Figure S23. Control study (no targeting substrate used) of the intracellular synthesis of mitochondria-targeting coumarin derivative. Compound 9, which is without a triphenylphosphonium group) was used in the experiment, instead of 10. Scale bar $=20$ $\mu \mathrm{m}$. 
DSNP 7 catalyzed coumarin light-up "Click" reaction

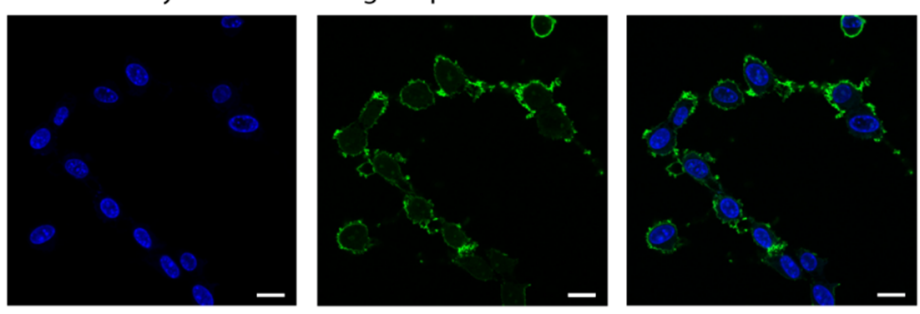

DSNP 12 catalyzed rhodamine 110 decaging
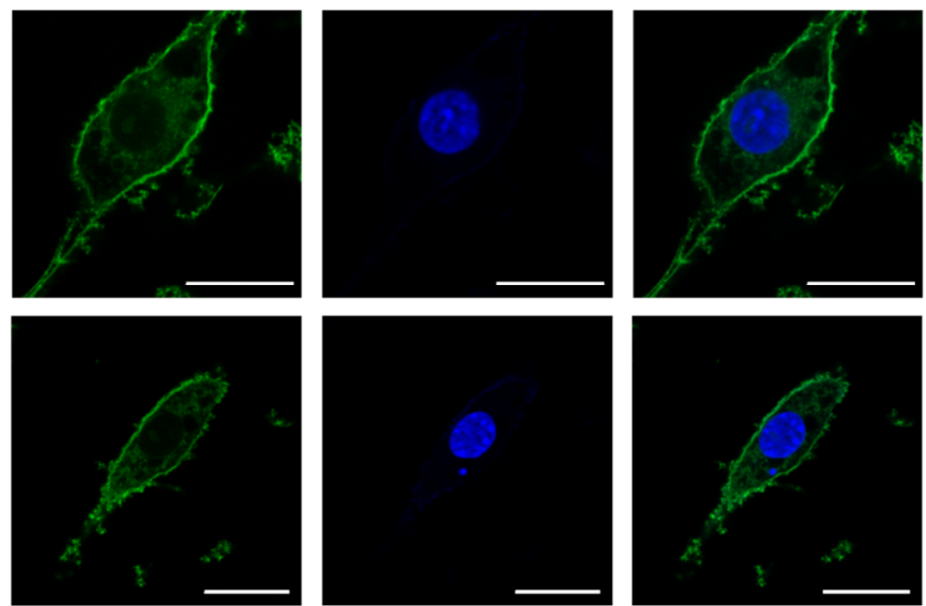

Fluorescein-labeled DSNP scaffold, no substrate used
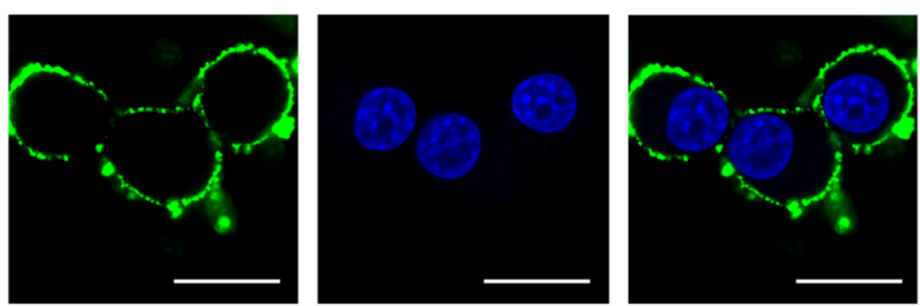

Figure S24. Additional confocal images for membrane-stained cells using DSNP-based catalysts or DSNP scaffold. Scale bar $=20 \mu \mathrm{m}$. 


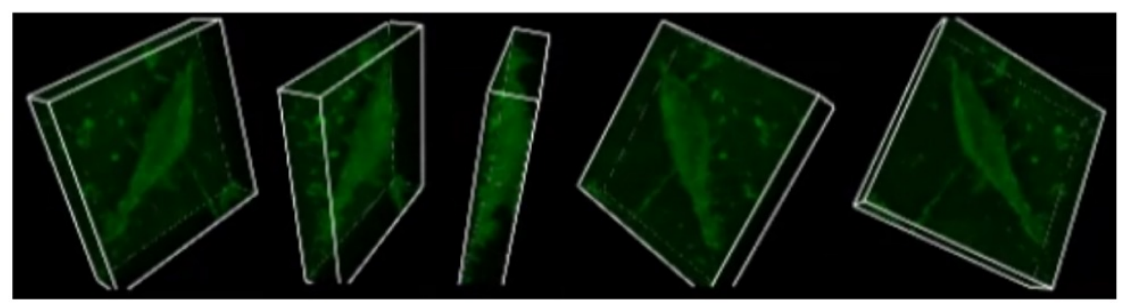

Figure S25. 3-D confocal image for membrane-stained cells using DSNP 12.

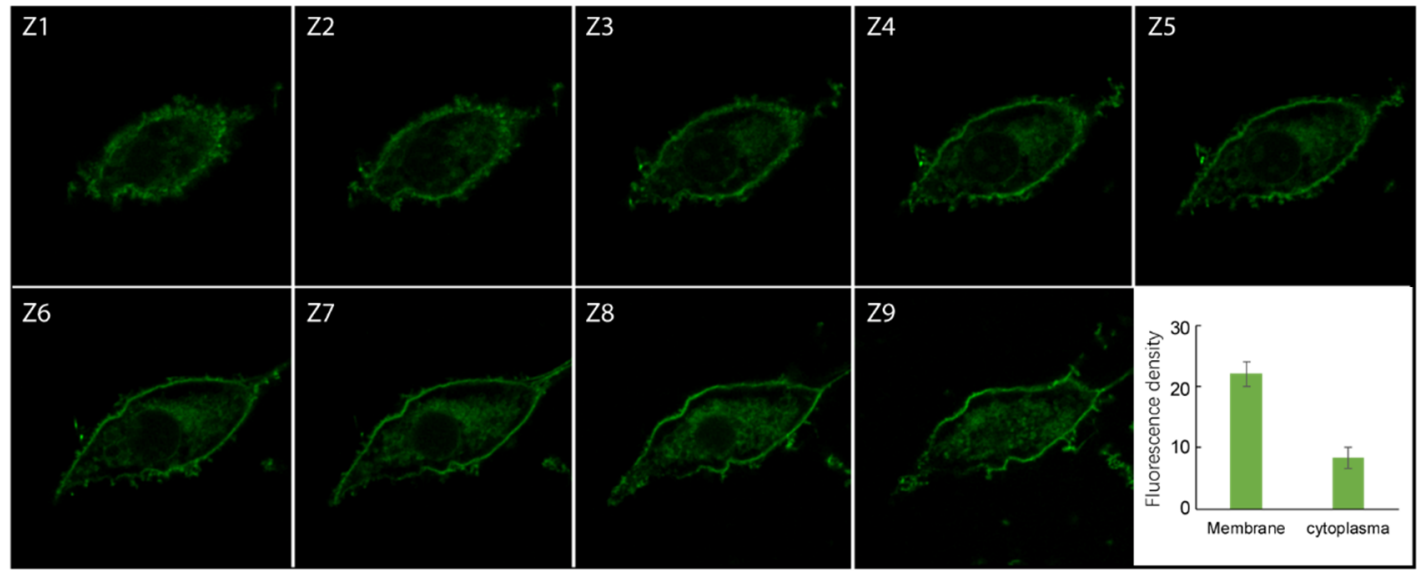

Figure S26. An example series of confocal images for z-stacking, and the corresponding fluorescence integration comparison of cell membrane and cytoplasm. Cells were stained by Rhodamine 110 (Pd-DSNP catalyzed).

Note S2. It is very difficult to differentiate the membrane and cytoplasm on the very top and very bottom stacks because of the geometry. Therefore, the integrated fluorescence intensity was relatively crude, and the actual intensity ratio of membrane/cytoplasma was likely to be higher. 


\section{Cytotoxicity Study}

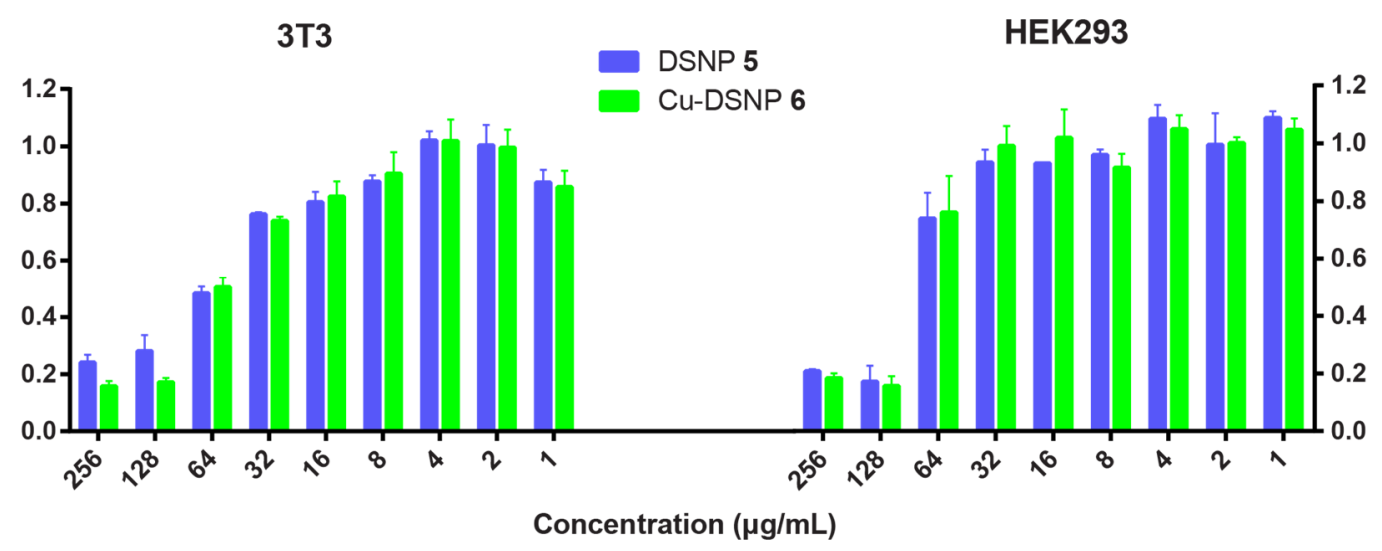

Figure S27. MTT assay result of 5 and $\mathbf{6}$ with 3T3 or HEK293T cells.

Discussion: The cytotoxicity of this DSNP catalyst cannot be ignored because of its ability in membrane disruption. In our intracellular catalysis study, even with low amount of DSNP catalyst, dead cells can be observed. We are actively working on the structural modification of the DSNP to achieve better biocompatibility while maintaining its membrane targeting effect. 


\section{References}

[1] J. A. Love, J. P. Morgan, T. M. Trnka, R. H. Grubbs, Angew. Chem. Int. Ed. 2002, 41, 4035-4037.

[2] Y. Bai, X. Feng, H. Xing, Y. Xu, B. K. Kim, N. Baig, T. Zhou, A. A. Gewirth, Y. Lu, E. Oldfield, S. C. Zimmerman, J. Am. Chem. Soc. 2016, 138, 1107711080.

[3] H. Dai, G. Liu, X. Zhang, H. Yan, C. Lu, Organometallics 2016, 35, 1488-1496.

[4] J. V. Passarelli, D. J. Fairfield, N. A. Sather, M. P. Hendricks, H. Sai, C. L. Stern, S. I. Stupp, J. Am. Chem. Soc. 2018, 140, 7313-7323.

[5] K. Sivakumar, F. Xie, B. M. Cash, S. Long, H. N. Barnhill, Q. Wang, Org. Lett. 2004, 6, 4603-4606.

[6] J. Luo, A. G. Oliver, J. Scott McIndoe, Dalton Trans. 2013, 42, 11312-11318.

[7] R. R. Chinthaparthi, C. S. R. Gangireddy, M. K. R. Kandula, S. K. Balam, S. R. Cirandur, J. Heterocyclic. Chem. 2015, 52, 1876-1882.

[8] Y. Bai, H. Xing, G. A. Vincil, J. Lee, E. J. Henderson, Y. Lu, N. G. Lemcoff, S. C. Zimmerman, Chem. Sci. 2014, 5, 2862-2868.

[9] S. T. Handy, M. Okello, J. Org. Chem. 2005, 70, 1915-1918. 